\title{
Alquimia, Ocultismo, Maçonaria: o ouro e o simbolismo hermético dos cadinhos (séculos XVIII e XIX)
}

\author{
Tania Andrade Lima \\ Depto de Antropologia do Museu Nacional/UFRJ; \\ Pesquisadora do CNPq \\ Marilia Nogueira da Silva \\ Bolsista do CNPq; Depto de Antropologia do Museu \\ Nacional/UFRJ
}

\begin{abstract}
Tome um crisol de ourives, passe-the gordura na parte interna e deite-the o nosso remédio, segundo a proporção requerida, tudo a fogo lento; e quando o mercúrio começar a fumegar, jogue o remédio encerrado em cera virgem ou em papel, pegue um carvão grande, aceso, especialmente preparado para este fim, e ponha-o no fundo do cadinho, deixando cozer em fogo violento; e quando tudo estiver liquefeito jogue em um tubo engordurado. Eis que assim terás Ouro e Prata finíssimos, segundo o fermento que tiveres empregado.
\end{abstract}

Tratado de Santo Tomaz de Aquino sobre a Arte da Alquimia, dedicado a frei Reginaldo (atribuído).

Os cadinhos da Casa da Moeda, Paço Imperial, Rio de Janeiro

No decorrer das escavações arqueológicas realizadas no Paço Imperial pelo Instituto do Patrimônio Histórico e Artístico Nacional, na década de 1980, foram recuperados vários cadinhos que foram associados, pelas arqueólogas responsáveis pelo trabalho, à Casa da Moeda que funcionou no prédio entre os séculos XVIII e XIX (PINHEIRO DA SILVA; MORLEY; FERREIRA DA SILVA, 1984).

Transferida da Bahia para o Rio de Janeiro em 1699, ela foi instalada no início do século XVIII em um conjunto de pequenas casas construídas pelos frades carmelitas em frente ao seu convento, no então Terreiro do $\bigcirc$, atualmente a Praça XV de Novembro, no centro da cidade. Junto com os Armazéns Reais foi transformada, em 1730, na Casa dos Governadores; posteriormente, em 1763, no Palácio dos Vice-Reis; e finalmente, com a chegada da corte portuguesa em 
1808, no Paço Real, posteriormente Paço Imperial. Ela funcionou no prédio até 1814, quando foi novamente transferida, desta vez para o prédio do antigo Museu de História Natural, conhecido como Casa dos Pássaros.

Recentemente, a amostra resultante dessas escavações foi confiada à guarda do Museu Nacional e, no processo da sua análise, os cadinhos chamaram nossa atenção em função de algumas de suas peculiaridades. Por se tratar de material ainda não estudado pela arqueologia histórica no Brasil, consideramos pertinente a sua investigação em maior profundidade.

Cadinhos (do latim catinu, significando tigela, bacia, cavidade) são vasos em forma de tronco de cone (FOTOGRAFIA 1), com ou sem tampa, feitos de materiais altamente refratários e temperados para resistir a aquecimento extremo, utilizados em fundição de metais, calcinação de substâncias ou em outras operações químicas que exijam um alto grau de calor. Resistem a temperaturas elevadas graças aos materiais de que são compostos, como argila, grafite, porcelana, ferro, prata, platina, entre outros, escolhidos em função da natureza das substâncias a serem processadas e das temperaturas a serem alcançadas. O grafite foi e ainda é bastante utilizado na confecção de cadinhos graças à sua infusibilidade, dureza e poder condutor, sendo capaz de suportar altas temperaturas sem fundir ou mesmo rachar. Já os de porcelana são impermeáveis, mas racham facilmente no fogo. Os porosos, de pasta grosseira, resistem bem às mudanças de temperatura, porém são permeáveis aos sais em fusão. Também designados como crisóis, seu tamanho varia em função da medida de capacidade, em geral marcada na sua base.

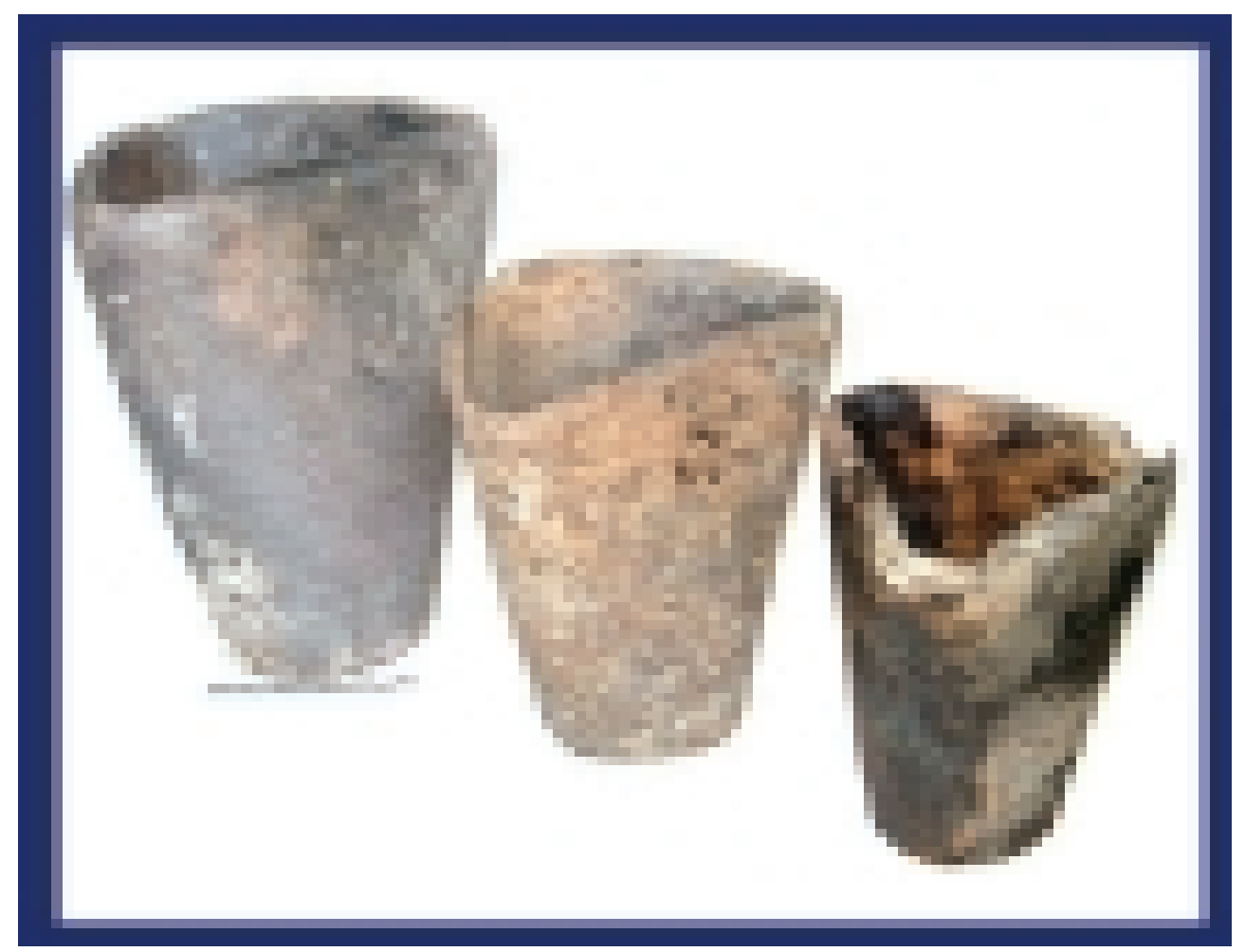

FOTOGRAFIA 1 - Cadinhos de diferentes tamanhos encontrados nas escavações da Casa da Moeda, Paço Imperial, Rio de Janeiro. Acervo do Museu Nacional do Rio de Janeiro. Fotografia de T. Andrade Lima. 
Utilizados no Brasil setecentista e oitocentista no processo de fundição do ouro, sobretudo em casas de fundição, casas da moeda e em áreas de mineração, os cadinhos vêm sendo recuperados em escavações arqueológicas, além de integrarem acervos de museus relacionados à história da mineração. Sobre os cadinhos utilizados no Rio de Janeiro especificamente, Eschewege (1944, p. 267) relatou no século XIX que

[...] outrora, também os cadinhos acarretavam grandes despesas ao Estado, principalmente antes do Rei chegar ao Brasil, pois, não existindo nenhum comércio direto, o Governo os comprava em Lisboa em terceira ou quarta mão, e enviava-os à sua custa para o Brasil, de modo que custavam dez vezes mais do que se fossem adquiridos diretamente. Hoje são usados os cadinhos de lpse (sic), que são recebidos no Rio diretamente dos vendedores boêmios, razão pela qual são adquiridos por preços muito mais baratos. Introduziu-se ainda, nas Casas de Fundição, o econômico sistema de pulverizar os cadinhos rachados e misturar o produto com uma porção de boa argila e fabricar novos cadinhos, de duração igual à dos primeiros. Os cadinhos de Hesse não foram usados, como afirma Mawe.

No século XIX, portanto, eles provavelmente vinham em grande parte da Boêmia, uma região rica em minérios, entre eles a grafite. Quanto aos do século XVIII desconhece-se a sua proveniência, porquanto aqui chegavam os já utilizados e reutilizados em Lisboa, sem que se tenha notícia de seus fabricantes originais.

Quanto à prática de reaproveitamento de cadinhos rachados ou quebrados, também referida no texto, ela se manteve até o final do século XIX, tal como relatado por Hartt (1881, p. 70):

Quando para fins metalúrgicos fazem-se cadinhos, que devem poder resistir a um grande calor e a repentinas mudanças de temperatura, para impedir que estes estalem juntam-se às vezes ao barro cru barro queimado, que se obtém reduzindo a pó cadinhos velhos.

Foram encaminhados ao Museu Nacional 136 cadinhos resultantes das escavações do Paço Imperial, sendo 21 inteiros, 28 fragmentados, e 87 fragmentos correspondendo às suas bases (PINHEIRO DA SILVA; MORLEY; FERREIRA DA SILVA, 1984, p. 1601. A maioria tem um elevado teor de grafite na sua composição, sendo de excelente qualidade. Além deles, há também exemplares produzidos a partir da pulverização de peças quebradas, reaproveitando-se a grafite, incorporada a uma nova pasta de argila. A análise dos componentes dos primeiros, encomendada pelas referidas autoras ao Instituto Nacional de Tecnologia (Laudo Sest, n 157/84, de 14 de junho de 1984), descartou a possibilidade de se tratar dos cadinhos de Hesse, mencionados por Eschewege, que segundo Laboulaye (1891) tinham a seguinte composição: sílica 0,709; alumínio 0,248; óxido de ferro, 0,033; magnésio, traços = 0,995.

Apenas os cadinhos com alto teor de grafite apresentam marcas de fabricação nas suas bases, quase sempre associadas a um número que corresponde à medida da sua capacidade (FOTOGRAFIA 2). As marcas de fabricação, razão maior deste estudo, são enigmáticas composições em torno do número 4 e do sinal da cruz, tanto simples - grega ou latina - quanto dupla, patriarcal (LEXIKON, 1990, p. 70), combinadas às iniciais LK, PS e IS, compondo três categorias distintas, com pequenas variações em cada uma delas (FIGURA 1,a-m).

Por entendermos que essas marcas poderiam iluminar a questão da origem dessas peças - sinalizando região, época e estabelecimento onde elas foram produzidas e as letras associadas indicando iniciais de fabricantes, tal como habitualmente se procede na arqueologia histórica - começamos a investigação. 


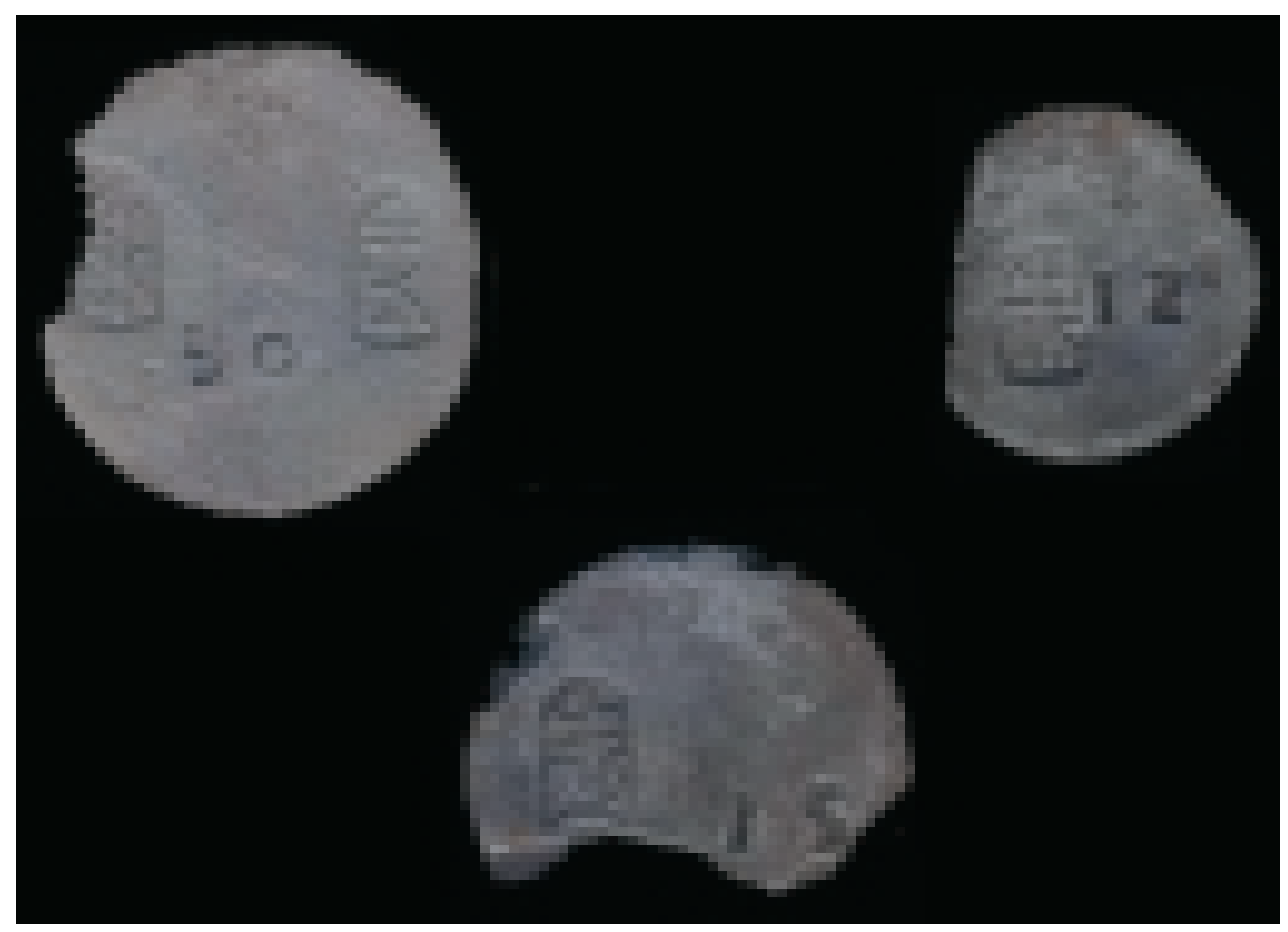

FOTOGRAFIA 2 - Marcas impressas nas bases dos cadinhos encontrados nas escavações da Casa da Moeda do Rio de Janeiro: à esquerda, emblema associado às iniciais LK; à direita, às iniciais IS; ao centro, às iniciais PS. Os números próximos correspondem a medidas de capacidade. Acervo do Museu Nacional do Rio de Janeiro. Fotografia de T. Andrade Lima.

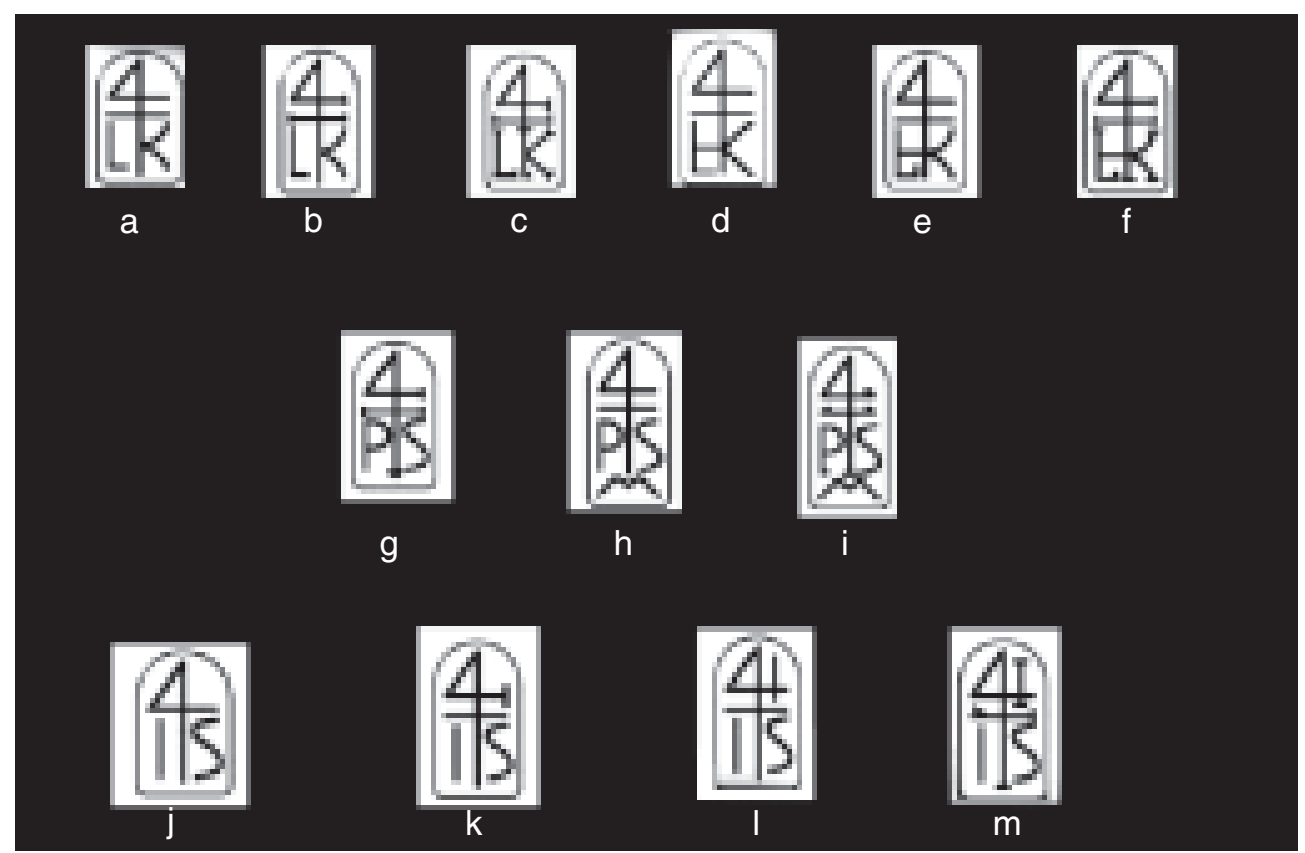

FIGURA 1- Marcas impressas na base dos cadinhos, distribuídas em três categorias: emblemas associados às iniciais LK e suas variações; às iniciais IS e suas variações; às iniciais PS e suas variações. Acervo do Museu Nacional do Rio de Janeiro. 
Antes, no entanto, entendemos ser necessário mapear a ocorrência dessas marcas em outros contextos relacionados à fundição de ouro e à mineração, em outras regiões do País, de modo a verificar se esses cadinhos ficaram restritos ao Rio de Janeiro ou se tiveram distribuição mais ampla.

Os cadinhos de Minas Gerais, Goiás e Bahia

Em Minas Gerais, por indicação da Casa da Moeda do Rio de Janeiro, analisamos os cadinhos da Casa dos Contos, em Ouro Preto, encontrados em 1974 pelo Sr. Eugenio Ferraz, funcionário do Ministério da Fazenda responsável pela reforma do edifício, transformado em centro de estudos do ciclo do ouro. Vários cadinhos de grafite foram achados casualmente no piso inferior do prédio, em um declive pavimentado com pé de moleque e recoberto por entulhos que formavam uma camada de $60 \mathrm{~cm}$ de profundidade (FERRAZ, 1985, p. 44-45; ver ilustração em GONÇALVES, 1989, p. 895).

Lá foram examinadas treze peças, das quais oito apresentam as mesmas marcas recuperadas na Casa da Moeda do Rio de Janeiro, sendo três associadas às iniciais LK (iguais às das Figuras 1-a, 1-d, 1-f), três às iniciais PS (iguais à da Figura 1-h) e duas às iniciais IS (iguais às das Figuras $1-j$ e 1-k). Provavelmente elas foram descartadas entre 1821 e 1844, período em que funcionou no prédio uma Casa de Fundição, transformada em seguida em Secretaria da Fazenda da Província de Minas Gerais.

Também em Minas Gerais foi examinado o acervo de cadinhos do Museu do Ouro de Sabará, onde apenas uma peça, igualmente de grafite, apresentou o mesmo emblema, associado às iniciais IS (FIGURA 2). As demais parecem ter sido fabricadas regionalmente, o que é sugerido pela existência de um molde em vinhático para fabricação de cadinhos. Não obstante a incompatibilidade entre suas dimensões e as das peças do acervo, o molde atesta indubitavelmente a existência de produção local.

Na cidade de Goiás, examinamos a amostra proveniente das escavações arqueológicas realizadas na Casa de Fundição do Ouro, atualmente depositada nas dependências da 17ª Sub-Regional do IPHAN. Tal como descrito na publicação dos resultados da pesquisa (FERREIRA DA SILVA; PARDI, 1989), verificamos a presença de cadinhos com alto teor de grafite, de excelente qualidade, ao lado de outros produzidos a partir da pulverização de peças inutilizadas. Em um dos cadinhos da primeira categoria constatamos a mesma marca, associada às iniciais LK (igual à da FIGURA 1-b).

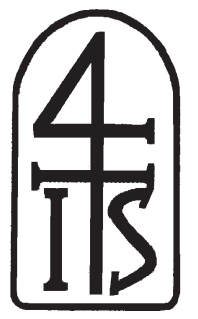

FIGURA 2 - Marca encontrada em um dos cadinhos do Museu do Ouro de Sabará, Minas Gerais, associada às iniciais IS. Acervo do Museu do Ouro de Sabará. 
Essas ocorrências em Minas Gerais e em Goiás sugerem que os cadinhos chegavam ao Rio de Janeiro e eram redistribuídos para o interior do País. As autoras mencionam notícias de que a Casa de Fundição de Goiás, por sua vez, os redistribuía para as Casas de Fundição de Cuiabá e de Vila Bela, em Mato Grosso, e investigações arqueológicas poderão vir a confirmar essas referências textuais.

Na Bahia, as pesquisas desenvolvidas por Carlos Etchevarne e equipe na Praça da Sé, em Salvador, resgataram cadinhos de pequeno porte e sem marcas, de composição diferente dos encontrados no Rio, em Minas e em Goiás, que são atribuídos pelo pesquisador responsável à Casa da Moeda, lá instalada em 1694, bem próximo à Praça da Sé (comunicação pessoal). Essa Casa da Moeda, transferida para o Rio de Janeiro em 1698, voltou a cunhar a partir de 1714 e permaneceu em funcionamento até 1830. Dispondo apenas dessa amostra, não temos elementos suficientes para afirmar se as marcas aqui estudadas ocorreram ou não na Bahia.

Nas Cartas Régias dirigidas a Manuel de Souza, oficial das Casas da Moeda do Brasil ao longo das três primeiras décadas do século XVIII (BOXER, 1965; Arquivo Nacional 1922) são constantes as referências a remessas de materiais, entre eles cadinhos, para as Casas de Fundição e Casas da Moeda no Brasil, sempre com ordem de pronto atendimento, "em caráter prioritário", "com brevidade", e assim por diante. Contudo, não obstante o máximo interesse e empenho da Coroa Portuguesa em facilitar a atividade de fundição, de modo a extrair da colônia a maior quantidade possível de ouro, as evidências de intensa reciclagem de cadinhos de grafite, tanto no Rio de Janeiro quanto em Minas Gerais e Goiás, sugerem que eles eram poucos e insuficientes para a demanda. $\bigcirc$ registro documental reforça essa insuficiência, como atesta um manuscrito datado de 1795 (ARQUIVO NACIONAL cod. 807, v. 5), de autoria do químico e metalúrgico João Manso Pereira:

\begin{abstract}
Por meio da torrefação nenhum indício deu esta mina de conter enxofre ou arsênico e por isso julgo que o seu mineralizador é ou o ácido marinho, ou o cretáceo, ou o fosfórico ou o arsenical. Mas não podendo ao certo decidir qual deles seja, por falta de vasos próprios para esta apuração, passei a fundir [...]. E não podendo com tudo isto obter um regulo, que me pudesse dar a conhecer o verdadeiro produto da mina, entrei na suspeita de que os cadinhos de que usava eram a causa do mau sucesso, e me quis a servir dos de Hesse geralmente aprovados por todos para semelhantes operações. Mas apenas existiram dois nesta terra, apesar das outras diligências que por eles fez o Doutor Ilmo. Exmo. Sr. Conde Vice-Rei, e com eles não tive melhor sucesso do que com os outros.
\end{abstract}

Com efeito, em setembro de 1808, possivelmente para resolver esse problema, o presidente do Real Erário expediu ofício autorizando a sua fabricação no Brasil, comunicando à Junta da Fazenda que

[...] por constar a boa qualidade dos cadinhos feitos por João Manso Pereira, e convir muito, que deles se use nas Casas de Fundição dessa capitania. Se ordena a essa Junta que haja de prestar todo o auxílio necessário à Fábrica dos mesmos cadinhos por conta da Real Fazenda, debaixo da direção de Do João Manço Pereira (sic) de maneira que se aprontem em suficiente quantidade para o uso dá Casas de Fundição.

É provável que a partir dessa determinação, que coincide não só com a abertura dos portos e o rompimento das práticas monopolistas 
portuguesas, mas também com o declínio da produção do ouro, tenha sido em parte atenuada a carência de cadinhos no Brasil, não obstante a prática da sua reciclagem ter persistido até o final do século, como relatou Hartt (1881).

A arqueologia de uma marca

Como um dos passos iniciais para a tentativa de identificação dessas marcas foi consultado o Dictionnaire Encyclopédique des Marques et Monogrammes, de Ris-Paquot (s.d.). Este dicionário efetivamente apresentou uma estonteante quantidade de emblemas que consistem em variações em torno do 4 e do sinal da cruz associados a letras, apresentadas como marcas corporativas de diferentes ofícios entre os séculos XV e XVIII, a saber: fundidores, ourives, gravadores, tapeceiros, talhadores de pedras, oleiros, louceiros, vidreiros, pintores, escultores, desenhistas, marceneiros (FIGURA 3). Porém, a esmagadora maioria delas é atribuída a livreiros e impressores da Europa Ocidental nos séculos XVI e XVII. Não há nenhuma menção a fabricantes de cadinhos.

Entre livreiros e impressores, a marca aparece com maior força na França, esmagadoramente em Paris, com cerca de 50 registros, secundada por Lyon, com cerca de 20, e também em Anvers, com apenas dois. Febvre e Martin (1992, p. 207) de fato mencionam Lyon e Paris como grandes centros editores, com mais de mil operários em atividade, com impressores e livreiros aglutinados em uma única e mesma corporação (FEBVRE; MARTIN, 1992, p. 216). Na Alemanha a marca aparece em Colônia, com onze registros, em Frankfurt com seis, e com menor popularidade, entre um e dois registros apenas, em Nuremberg e Ulm; na Áustria, em Viena e Strasburgo; na Suiça, em Zurich; na Bélgica, em Bruxelas; na Itália, em Roma, Veneza e Nápoles; na Espanha, em Madri e Saragoça.

Qual a relação entre impressores / livreiros franceses dos séculos XVI e XVII e fabricantes de cadinhos do século XVIII foi a primeira pergunta que se impôs, diante do manancial de informações fornecido pelo Dictionnaire de RisPaquot. Em função dela, a pesquisa foi orientada para o surgimento da tipografia e sua relação com a metalurgia, com a fusão de metais e, por conseguinte, com a utilização de cadinhos.

De fato, uma gravura datada de 1568, de autoria de Jost Amman (MARTINS, 1996), mostra o processo de fundição de tipos e em meio ao equipamento utilizado aparece um cadinho (FIGURA 4).

encaminhamento nessa direção, contudo, não obstante consideravelmente aprofundado, pouco esclareceu senão que alguns ofícios eram estreitamente relacionados, por exigirem a habilidade de trabalhar com fundição de metais, e pela utilização de técnicas comuns. Deste modo, um artífice que as dominasse qualificava-se para o exercício de diferentes ofícios. A tipografia serviuse amplamente das técnicas da ourivesaria para a fabricação de matrizes individuais para os tipos, aproximando ourives de gravadores e de tipógrafos, entre muitos outros, diluindo especializações profissionais. 


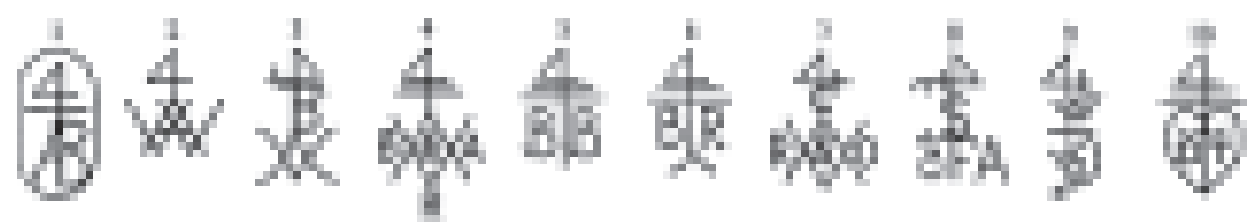

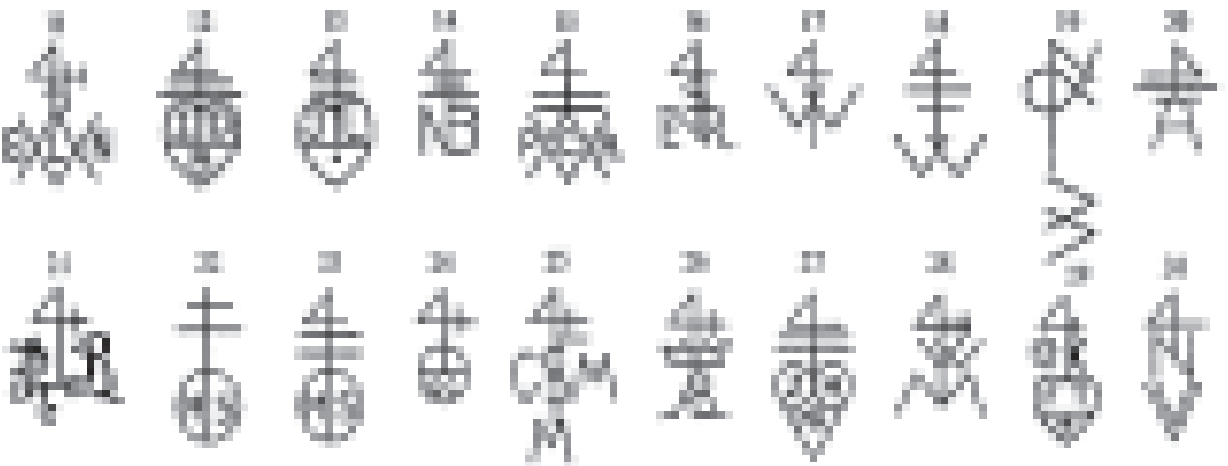

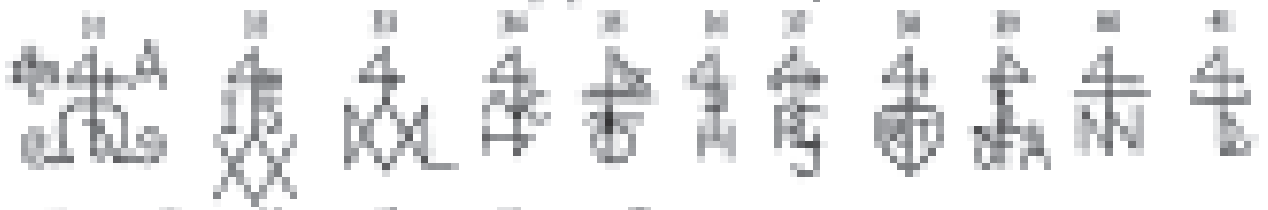

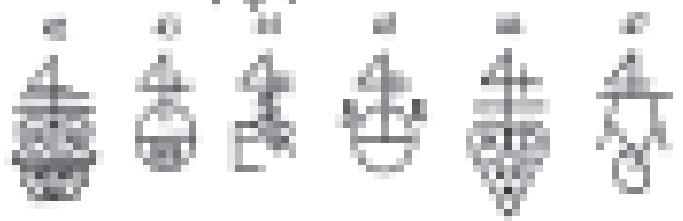

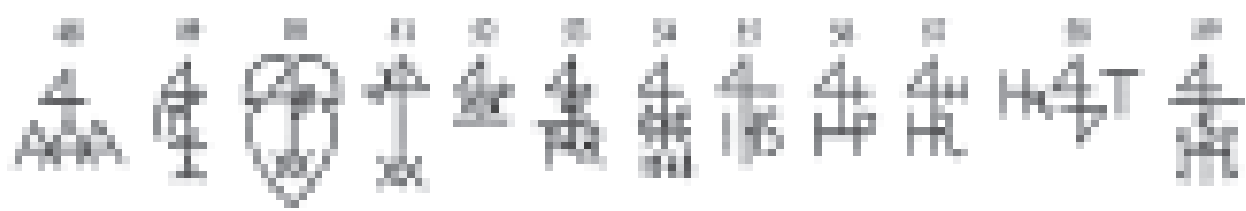

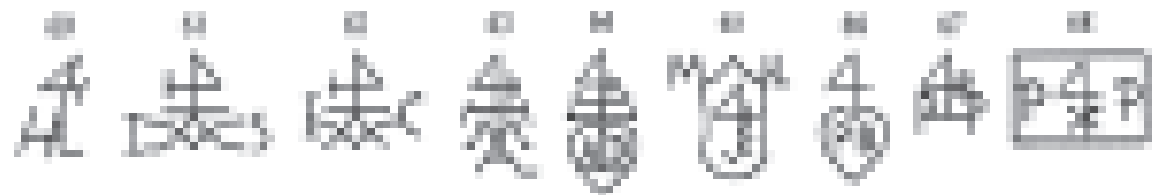

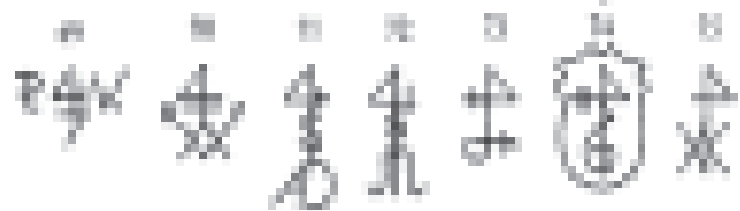

FIGURA 3 - Emblemas de livreiros, impressores e outros ofícios entre os séculos XV e XVIII, segundo Ris-Paquot (s/d). Acervo da Biblioteca da Universidade Federal de Juiz de Fora, Minas Gerais.

1- Livreiro. Antoine Bulifon, Nápoles, 1675

2- Impressor-livreiro. Wichel (André), Paris, 1556-1567

3- Livreiro. Brumen (Thomas), Paris, 1578

4- Livreiros associados de Lyon. Borde Philippe, Laurent Armand e Claude Rigaud, 1653-1657

5- Impressor. Bounyn (Benoist), Lyon, 1491-1528

6- Livreiros associados à Lyon. Boissat (Horace) et Georges Renée, 166 1-1665 
7- Livreiros associados à Lyon. Rigaud et Obert, 1628

8- Impressor-livreiro. Groulleau (Etienne), Paris, 1547

9- Livreiro-impressor. Hichman (Damian), Paris, 1521-1524

10- Livreiro. Denys (Thierry), Paris, 1648

1 1- Livreiro de Paris. None (Guillaume), 1577

12- Livreiro. Bonilla (Juan de), Saragosse, Espanha, 1620

13- Livreiro. Lyon (Jacques), Lyon, 1693

14- Livreiro. Buon (Nicolas), Paris, $1612-1618$

15- Livreiros associados. Marca dos irmãos Rigaud (Pierre, Claude), Lyon, 1646

16- Jogo de tapeçaria. Raes (lean). Primeira metade do século XV

17- Impressor-livreiro em Frankfurt. Jean Wechel, associado a Petrus Fischerus em 1583-1591

18- Livreiro de Frankfurt. Wilhelmus Fitzerus

19- Impressor de Londres. Wynklyn de Word, 1491-1535

20- Impressor e editor. André Gessner, Zurich, 1559

21-Impressores. Pichore (Jehan) e Laistre (Remy), Paris, 1497-1504

22- Impressor-livreiro. Sessa (Melchior), Venise, 1570

23- Marca dos herdeiros de Sessa

24- Livreiro de Paris. Chevallon (Claude), 1526-1531. Dado para sua sucessora a viúva Charlotte Guillard, 1540-1552

25- Livreiro. Munich (Constantinus), Cologne, 1630

26- Impressor parisiense. L Roy et Ballard (Robert), 1551-1594

27- Huguetan (Antoine). Novos sócios, MR em 1673

28- Impressor-livreiro. Wyon (Marc), Douai, 1618

29- Impressor-livreiro. Taga (François) e Pierre Taga, 1649

30- Impressor. Wolff (Nicolas), Lyon, 1498-1512

31- Livreiro. Martin (Boillon ou Boullion), Lyon, 1500-1513

32- Livreiro. Sonnius (Jean), associado à companhia "Grande Navire", Paris

33- Desenhista e gravador em buril. Muller (Hermann), nascido em Amsterdam, final do século XV

34- Livreiro. Maternus Cholinus, Cologne, 1584

35- Impressor-tivreiro. Balsarin (Guillaume), 1503

36- Editor. Pierre Henning, Cologne, 1609

37- Livreiro. Granjon (Robert), Paris, 1549-1573

38- Impressor-livreiro. Rolin (Thierry), 1670-170 1

39- Livreiro-impressor. Janot (Denys), Paris, 1529-1545

40- Impressor-livreiro. Nicolas-Nivelle, Cologne, 1583

41 - Impressor. Durand (Laurent), Lyon, 1623

42- Impressores. Bounyn (Benoist) e Blaufoys (Jean), Lyon, 1525

43- Impressor-livreiro. Rembolt, Paris, 1491-1518

44- Antiga tapeçaria de Bruxelas, Bélgica

45- Pintor. Remboldt (Berthold)

46- Livreiro. Dézallier (Antoine), Paris, 1699

47- Impressor-editor. Gessner (Ándré), Zurich, 1559

48- Gravador. Muller

49- Sinal maçônico ou lapidário de um ourives talhador de pedra. Igreja Saint-Pantaléon, Troyes

50- Esmalte de Limoges, coleção "Le Carpentier"

51 - Talhador de pedra de uma loja maçônica.

52- Tapeceiro de Beauvais (Oise), 1664

53- Antiga tapeçaria de Bruxelas

54- Pintor-vidreiro. Igreja de Saint-Etienne du Mont, Paris

55- Monograma de Cristo, Toscana, 1475

56- Pintor-vidreiro não identificado, 1684

57- Rheydt (Hans van), ebanista, marceneiro de Cologne, início do século XVII

58- Escultor de alabastro não identificado, século XVI

59- Faiança antiga, Suíça

60- Desenhista e gravador. Allard ou Allaerds (Hugnes)

61 - Pintor. Swart (Jean de Groningue), Escola Holandesa, século XVI

62- Pintor flamengo. Coonhuuse (Jacques Van de), Bruges, 1578

63- Pintor. Mayer, Zurich, Suíça

64- Antiga tapeçaria pertencente a M. des Varennes. As letras "A D" estão colocadas dentro de um coração suplantado por uma cruz de muitos braços.

65- Punção do oleiro Harscher (Martin), Nuremberg, 1453-1523

66- Pintor e gravador. Brebiette (Pierre), nascido em Mantes-sur-Seine, 1598

67- Vitral alemão de 1678. Potter (Paul)

68- Pintor flamengo. Porbus (Pierre), nascido em Gouda, 1510-1584

69- Fundidor e escultor. Peter Vischer, Nuremberg, 1530

70- Livreiro. Robert Fouet, Paris, 1610-1617

71 - Pintor desconhecido da Escola Flamenga. Fim do século XV, início do século XVI

72- Pintor-vidreiro de Troys. Igreja de Saint-Nizier

73- Pintor de vidros de Troyes. Vitral da Igreja de Saint-Nizier

74- Tapeçaria de Dijon. Autor desconhecido

75- Sinal maçônico ou lapidário de que se serviram os arquitetos, mestres, ourives e talhadores de pedra participantes de lojas maçônicas 


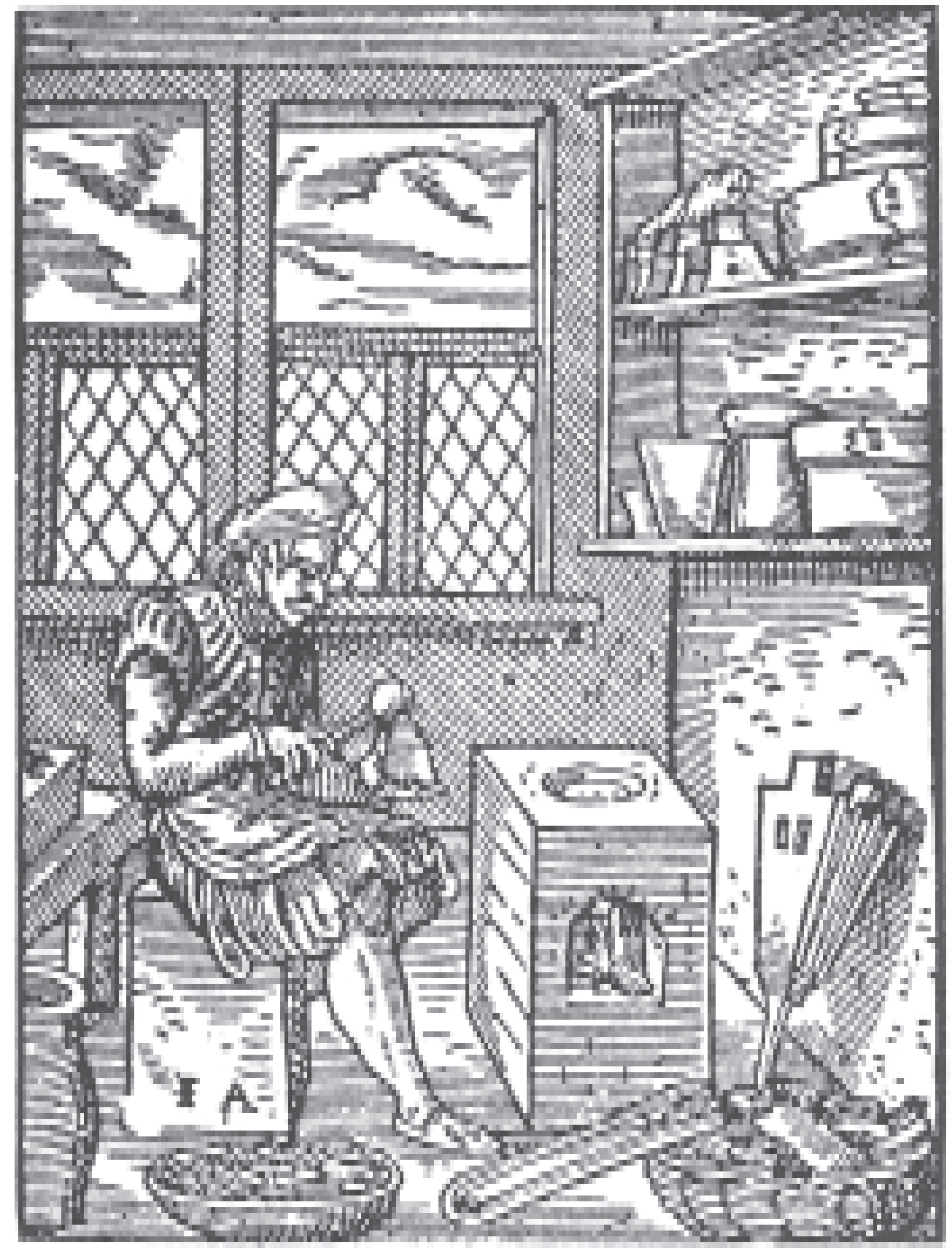

FIGURA 4 - Gravura datada de 1568, de autoria de Jost Amman, onde aparece um cadinho em meio ao equipamento utilizado no processo de fundição de tipos. In Wilson Martins, A palavra escrita. História do livro, da imprensa e da biblioteca (1996, p. 166). 
João Manso Pereira, acima citado como fabricante de cadinhos, exemplifica bem essa diluição: autodidata, era simultaneamente metalúrgico, ceramista, mineralogista e naturalista, além de professor de latim, grego e hebraico (DREYFUS, 1953; FILGUEIRAS, 1990; LUCAS, 1998), dominando portanto as "duas artes do fogo", como as designou Lévi-Strauss (1996, p. 18): a metalurgia e a cerâmica, estreitamente ligadas.

A utilização de sinais distintivos para caracterizar propriedade é muito antiga na história da humanidade, e na Baixa Idade Média era freqüente mercadores colocarem marcas nos fardos transportados. Logo esses sinais passaram a identificar a origem de mercadorias ou mesmo os artífices que as produziam, particularmente entre impressores e livreiros (FOURNIER, [s.d.]; McMURTRIE, 1938, p. 289). Com um caráter acentuadamente ornamental, essas marcas foram se tornando mais e mais complexas, revestiram-se de conteúdos simbólicos, expressando a insígnia da oficina e eventualmente uma divisa. Esta teria sido a origem e função dos emblemas utilizados como marcas, tal como os que foram apostos nos cadinhos.

Além desses aspectos chamou nossa atenção, ainda no Dictionnaire de Ris-Paquot, o fato de que pelo menos três emblemas com variações em torno do 4 são referidos como sinais maçônicos ou lapidários, atribuídos a talhadores de pedra, ourives, mestres de obras, e adotados por eles como marcas individuais utilizadas em canteiros de obras. Marcas como essas podem ser vistas ainda hoje nas pedras de catedrais, igrejas e castelos na Europa Ocidental.

Não há dúvida de que o uso de marcas é antigo em todos os ofícios, mas a sua associação à Maçonaria, no caso, como marcas escolhidas por maçons e que os identificam como membros da Ordem por toda a vida, sugeriu uma nova senda de investigação. Esta possibilidade tornou imprescindível a consulta à literatura ocultista, de modo a se ter acesso a esse universo a partir de uma perspectiva êmica, fundamental para o seu correto entendimento.

Guénon (1993), explanando alguns símbolos herméticos, refere-se a essas marcas, que designa como "quatro de cifra", descrevendo-as como um conjunto complexo formado pelo algarismo 4, ao qual são acrescentadas linhas suplementares, horizontais e verticais, que se combinam com letras ou monogramas. Atribui o signo a uma sociedade secreta de impressores e livreiros, embora admita que ele seja comum a um grande número de corporações. Reconhece sua relação direta com iniciações de ofício, entendendo que, a julgar pelos contextos em que ela aparece, trata-se de uma marca do grau de mestre.

O fato de o "quatro de cifra" ser representado em orientações opostas é por ele interpretado como expressão de diferentes corporações ou de diferentes ritos em sociedades secretas, aparecendo algumas vezes associado também a um globo ou a um coração (FIGURA 3). Para Davis (1935) o globo e a cruz são uma representação pagã da divindade romana Mercúrio, o Hermes dos gregos. O coração, por sua vez, se esquematizado, corresponde ao signo invertido do enxofre alquímico.

Para Guénon (1993) não há qualquer dúvida de que se trata de um símbolo quaternário, não tanto pela sua semelhança com o algarismo, mas porque em todas as marcas em que este algarismo figura, tem a forma exata de uma cruz em que a extremidade superior do esteio vertical e uma das extremidades do braço horizontal estão ligadas por uma linha oblíqua. Com seu caráter axial, o "quatro de cifra" representa o eixo do mundo. A linha oblíqua que une as extremidades do 
topo e de um dos braços da cruz, fechando um dos ângulos, forma por sua vez um "olho", o olho que tudo vê. E a cruz é essencialmente um símbolo do quaternário, desde os pitagóricos. Quando presente em marcas ocultistas seria um indicador do mais alto grau iniciático. Frutiger (1999) entende que a cruz dupla, cardinalícia, ao duplicar as horizontais transforma o sinal em uma cruz de categoria mais elevada. Já Pinto (1948) designa o signo do 4 como "cruz pervertida", citando Delalain em sua obra Inventaire des marques d' imprimeurs et libraires de la collection du Cercle de la Librairie, para quem os dois ramos que se unem formando um 4 seria uma forma de dissimulação do sinal sagrado, identificada entre livreiros de Lyon perseguidos por motivos religiosos ao final do século XVI, uma estratégia que permitia aos iniciados a sua livre utilização.

Outra referência para um possível significado para essas marcas foi encontrada no Webster's Revised Unabridged Dictionary, edição de 1913. Chamou nossa atenção o fato de que o termo em inglês para cadinho, crucible, tem sua origem na palavra crucibulum (latim tardio), de mesma acepção, ambos derivando de crux (cruz). O mesmo ocorre com a palavra que designa cadinhos no holandês kroes, no sueco krus, no dinamarquês kruus, no italiano crogiolo, no francês creuset, no espanhol crisol, que em português é sinônimo de cadinho. Essa raiz, comum a grande parte da Europa Ocidental, seria decorrente, segundo o Webster, do fato de os antigos alquimistas adornarem os cadinhos com uma cruz, assim marcados com a finalidade de evitar que forças negativas estragassem as operações alquímicas. $\bigcirc$ termo crucibulum, por sua vez, é sinônimo de catinu, de onde deriva em português a palavra cadinho, como já assinalado.

Foram abertas, portanto, três possíveis vias para a interpretação das marcas: a primeira, relacionada às corporações de ofícios, sugerindo tratar-se, no caso, de uma marca corporativa. A segunda, remetendo a segredos e práticas alquímicas, e a terceira apontando a possibilidade de tratar-se de marcas individuais maçônicas.

As corporações de ofícios medievais

As origens das corporações de ofícios, aqui apresentadas sumariamente apenas para introduzir a questão, são controversas. Várias hipóteses são levantadas para explicar o fenômeno do seu surgimento praticamente simultâneo em grande parte da Europa Ocidental, a partir do século XI, em especial na França, Alemanha, Inglaterra, Países Baixos, Itália ou, de modo mais geral, nos locais em que o fenômeno da urbanização se fez presente.

Uma das mais discutidas é a sua derivação dos collegia, organizações corporativas das artes e dos ofícios na Roma antiga. Desmanteladas com as invasões bárbaras, elas praticamente se extinguiram, sobrevivendo apenas em regiões da Itália influenciadas por Bizâncio. Nos demais territórios do império romano elas teriam ficado em hibernação até serem despertadas pelo renascimento econômico, alcançando seu apogeu entre os séculos XII e XIV. Contudo, em seu consagrado estudo sobre a história econômica e social da ldade Média, Pirenne (1968, p. 187) desconsidera essa hipótese, preferindo atribuir o fenômeno do seu espraiamento generalizado pela Europa a um anseio coletivo pela livre associação. 
surgimento das corporações de ofício é por ele explicado na circunstância do renascimento econômico do século XII, com o crescimento das cidades e a intensificação da produção e do consumo. A aglomeração crescente de pessoas nos núcleos urbanos em expansão criava uma demanda por gêneros, necessários ao seu abastecimento, e por produtos, imprescindíveis ao seu funcionamento. Atraídos pelas possibilidades geradas por essa dinâmica, para lá convergiam diferentes classes de artífices em busca de compradores para seus produtos e serviços. Os já estabelecidos sentiam-se cada vez mais ameaçados pela afluência contínua de novos artesãos e, se o anseio pela livre associação de que nos fala Pirenne já se fazia sentir com a urbanização, para os artífices ela se tornou uma estratégia de defesa contra essa concorrência externa.

A idéia de união e solidariedade que vinha se manifestando nos trabalhos coletivos de inspiração religiosa - em especial na construção das monumentais catedrais góticas - executados por centenas de trabalhadores sob o comando de um mestre de obras, tornou-se crucial para a sobrevivência profissional. Não obstante imbuídos de espírito de fraternidade cristã e de ajuda mútua em caso de necessidade, os artesãos organizaram-se em confrarias, a partir do século Xl, gravitando em torno de mosteiros e igrejas, tendo à frente uma pessoa de comprovada virtude. Se inicialmente essas confrarias agruparam diferentes categorias profissionais, em um segundo momento elas passaram a aglutinar tão somente pessoas que exerciam um mesmo ofício.

Bem sucedidas na implantação de um modelo de organização do trabalho, elas multiplicaram-se de tal forma que para cada ofício constituído surgiu uma corporação voltada para a proteção dos seus interesses, como a dos tecelões, dos tintureiros, alfaiates, sapateiros, curtidores, seleiros, peleiros, carpinteiros, pedreiros, canteiros, escultores, vidreiros, ferreiros, telheiros, latoeiros, ourives, gravadores, entre muitas outras.

Contudo, ameaçados pelo seu fortalecimento, os poderes constituídos - no caso, as autoridades comunais e o clero - acionaram prontamente seus mecanismos de controle, colocando as corporações sob sua supervisão e vigilância, na medida em que não apenas os interesses dos que produziam precisavam ser protegidos, mas também os daqueles que consumiam.

As relações de produção e consumo passaram a ser regidas por regulamentos específicos de cada corporação, onde os direitos ao exercício da profissão thes era assegurado, protegendo-os da concorrência, enquanto seus membros detinham o monopólio do seu respectivo ofício. Por outro lado, os que consumiam ficavam protegidos de fraudes e falsificações, de produtos de qualidade duvidosa e de abusos na sua comercialização. Para Pirenne, esses dois fatores associados foram os responsáveis pelo sucesso dessas corporações, ou seja, a defesa dos interesses tanto dos artífices quanto dos consumidores.

Não obstante as especificidades de cada região, de modo geral as corporações se estruturaram de forma semelhante, detendo sempre a exclusividade do mercado local. Unidos por direitos e deveres, regidos por normas estritas e rigidamente hierarquizados, os artífices construíram uma organização tripartida fundada na qualificação profissional e nos conhecimentos acumulados acerca do ofício, dividindo-se em aprendizes, companheiros e mestres. Eram estes últimos que detinham a propriedade das ferramentas, da matéria-prima e das oficinas, que funcionavam também como lojas, possibilitando a venda dos produtos 
1. Para um maior aprofundamento ver Berthelot 1885; Eliade 1979; Goldfarb1987. diretamente ao consumidor. Cabia-lhes a iniciação dos aprendizes que, após um longo adestramento, progrediam para a categoria seguinte através de exames de aptidão, já que o ofício só poderia ser praticado por aqueles que comprovassem capacitação. Nesse prolongado processo de acumulação de experiência, os artífices guardavam rigoroso segredo de suas técnicas.

Eram proibidos a abertura de oficinas e o comércio extramuros, fixandose distâncias rígidas para essa interdição a partir das muralhas dos burgos. Tampouco produtos de fora podiam ser vendidos intramuros, salvo nas épocas de realização de feiras. Eram-lhes exigidas legitimidade de nascimento e boa conduta, bem como ser cidadão local. Proteção e ajuda mútua em caso de necessidade, doença e morte eram asseguradas e nenhum artífice podia enriquecer à custa de outro. Transgressões aos respectivos códigos de normas disciplinares, aos aspectos morais e práticos da formação, progressão e exercício profissionais eram fiscalizadas pelos juízes do ofício, além do controle mantido pelas autoridades locais.

Cada corporação, cada oficina, ou mesmo cada mestre tinha suas insígnias particulares. Em caso de falecimento, a viúva e os filhos do artífice eram amparados e podiam continuar a exercer o ofício, desde que devidamente habilitados. Quando não, o juiz do ofício designava alguém capacitado a gerir o negócio. As insígnias via de regra eram herdadas e mantidas pelos sucessores, que faziam pequenas alterações no emblema sinalizando a sucessão.

A partir do século XIII, fortalecidas, as corporações passaram a reivindicar maior autonomia. As reações logo se fizeram sentir, mas mesmo assim elas acabaram conquistando maior independência e poder político, até que começaram a perder força, minadas por descontentamentos internos e pelas transformações das relações de trabalho no mundo moderno.

A alquimia, suas origens e fundamentos

A alquimia, exposta aqui de forma bastante abreviada e restrita aos interesses do presente estudo', se para uns é uma filosofia hermética, uma doutrina espiritual, arte sagrada ou ciência oculta, para outros é um método, uma técnica que se funda em um conjunto coerente de teorias relativas à constituição da matéria, à formação das substâncias inanimadas e viventes. A primeira perspectiva, que a considera como um grandioso sistema filosófico objetivando primordialmente penetrar nos mistérios da criação e da vida (READ, 1951), tentou trabalhar a natureza no sentido do seu aperfeiçoamento. E a segunda, não necessariamente dissociada da anterior, constituiu o embrião da química moderna, surgida na segunda metade do século XVIII.

Sua origem é nebulosa, imprecisa, e parece resultar de diferentes tradições do mundo antigo, mesclando saberes imemoriais transmitidos quer oralmente, quer através de textos herméticos, e entrelaçando operações químicas, misticismo, magia, filosofia, astrologia.

Suas raízes mais fundas parecem estar entranhadas nos primórdios da metalurgia, na observação das transformações operadas nos metais em contato com o fogo em temperaturas muito elevadas, alterando seu estado, coloração e forma. Eliade (1 979) mostra de que modo as atividades de extração de metais in 
natura, de obtenção de novos metais e produção de ligas metálicas - misteriosas porquanto pouco compreendidas e protegidas por segredos - foram mitificadas, sacralizadas, e fundidas a práticas mágico-religiosas desde tempos muito recuados, o que viria a inspirar posteriormente a formação de confrarias de caráter iniciático e de sociedades secretas.

Dessa estreita relação com a metalurgia surgiu a concepção alquímica da Mãe Terra como um ser que gesta metais, entendidos como organismos vivos em seu interior, compostos sempre dos mesmos elementos, enxofre e mercúrio, só que em proporções variáveis. Em seu ventre ficavam armazenados "embriões" metálicos - os minerais - que iam se desenvolvendo, amadurecendo e se transformando paulatinamente em diferentes metais, até alcançarem o aprimoramento maior, quando se transformavam em ouro, o mais perfeito de todos, por ser capaz de resistir ao fogo e a elementos corrosivos sem perder sua cor ou brilho.

Esses diferentes metais, entre eles o cobre, o chumbo e o estanho, correspondiam portanto a diferentes etapas de maturação. Ao serem extraídos das minas sofriam uma interrupção no processo do seu amadurecimento e aperfeiçoamento, nascendo deste modo imperfeitos, inacabados, abortados, em decorrência do parto prematuro. Mas quando se dava à natureza tempo suficiente para que a gestação chegasse a termo, todos se transformavam em metais perfeitos, ou seja, em ouro.

A proposta fundamental da alquimia consistia em ajudar a natureza a acelerar esse longo e lento processo multimilenar através de um poderoso agente transformador capaz de substituir o decurso do tempo: o pó de projeção ou pedra filosofal, pedra sagrada dos sábios, freqüentemente descrita como um pó vermelho. Obtido através de fórmulas secretíssimas, ao ser lançado sobre o metal em fusão, transmutava metais comuns em metais nobres, como ouro, prata e platina. $\bigcirc$ fato de eles serem compostos dos mesmos elementos permitia a transmutação de um em outro mediante tão somente uma recombinação das suas proporções.

Da mesma forma que a metalurgia transformava os embriões (minerais) em metais, assim a alquimia transmutava todos os metais em ouro, acelerando o ritmo natural da Mãe Terra. Nisto consistia a Grande Obra, a Opus alchimica, uma seqüência de procedimentos desenvolvidos

\footnotetext{
[...] a partir do princípio de que o mais alto provém do mais baixo e vice-versa, e de que tudo é obtido do único por meio da conjunção dos opostos; a Obra, partindo da união do Sol com a Lua, engendra o sopro vital: o Mercúrio, cuja aura é a Terra. Ele é o fermento da transmutação dos metais; separa a terra do fogo e o que é precioso do que é grosseiro; elęva-se da terra ao céu e retorna para unir o que está embaixo ao que está acima. É a força que penetra tudo que é sólido e assim cria-se o microcosmo, a imagem do universo. Esse é o processo alquímico [...] (VARGAS in GOLDFARB, 1987, p. 25-26).
}

Sua alegoria é oróboro, a serpente que engole a própria cauda.

No plano simbólico, traçando um paralelismo entre matéria e alma, da mesma forma que os metais impuros podiam alcançar a perfeição incorruptível do ouro, os alquimistas, na sua imperfeição humana, poderiam alcançar a mesma perfeição em sua essência espiritual. Tal como a matéria-prima é torturada pelo fogo, a alma é torturada pelo sofrimento e da mesma forma purificada em sucessivas etapas. Desta maneira, entendendo matéria e espírito como indissociados, a 
transmutação da matéria tornou-se simbolicamente para os alquimistas a transmutação espiritual do ser humano, seu aprimoramento interior com vistas à sua integração harmônica ao cosmos.

Ao buscar a compreensão da natureza mais íntima das coisas,

[...] busca(va)m a essência metafísica da aparência material ou fenomenológica e por meio da inteligência (mercúrio) ingressa(va)m no Santuário da Natura naturans, da qual a Natura naturata, estudada pela ciência comum, é tão somente a manifestação exterior ou visível (MAGISTER, 1946, p. 143).

No Oriente, a alquimia parece ter surgido na China imbricada à metalurgia, somando velhas crenças e ensinamentos a antigas receitas, e condensando-os em um corpo de conhecimentos que interagia fortemente com a filos,ofia taoísta já por volta do século V A.C., recebendo ainda possíveis influências da Índia. Fundando-se no princípio dualista dos opostos complementares ying e yang, o primeiro feminino, passivo, lunar, o segundo masculino, ativo, solar, a alquimia chinesa aspirava à busca da longevidade e da imortalidade. Estas seriam alcançadas por quem conseguisse produzir um elixir, fermento da transformação, capaz de proporcionar o equilíbrio perfeito entre o ser humano e o cosmos, o elixir da longa vida.

"divino cinábrio", vermelho como o sangue, mercurial, foi de início a grande fonte de regeneração e vitalidade, substituído pouco a pouco pelo ouro alquímico, que no entanto não tinha qualquer valor de troca na China antiga. Apenas ele cumpria melhor, pelos seus atributos, a função simbólica que the foi atribuída no sistema dualístico:

[...] o princípio yin ficaria a cargo do mercúrio, renascido pela mortificação do cinábrio, parte feminina e receptora; (esta) seria fecundada pelo princípio masculino yang, um princípio sulfuroso, ativo e penetrante, e dessa união nasceria o ouro alquímico. Esse processo deveria ser acompanhado de grande ritualística, com o intuito de atrair forças do "grande universo" que ajudassem a realizar a obra (GOLDFARB, 1987, p. 72).

Acelerado pelos processos alquímicos, esse ouro possuía uma vitalidade superior que preservava os corpos da deterioração, o que lhes permitia alcançar a imortalidade.

rejuvenescimento e a longevidade no plano da experiência interior deveriam ser obtidos, segundo o taoísmo, através do regresso ao estágio prénatal, ao útero, alcançado através da fusão dos ingredientes no forno.

Eis porque Ju-lai, em sua grande misericórdia, revelou o método do trabalho (alquímico) do Fogo e ensinou os homens a penetrar de novo no útero para refazerem sua natureza (verdadeira) e (a plenitude do) seu quinhão de vida (ELIADE, 1979, p. 94).

A cura era, portanto, obtida através de um retorno simbólico às origens do mundo, e esta volta às origens, esse reviver da criação do mundo permitia ao indivíduo nascer novamente e recomeçar a viver com uma reserva intacta de forças vitais, livrando-o da degenerescência e assegurando-the a longevidade e a imortalidade.

A transmissão do saber alquímico entre os chineses tinha um caráter iniciático, revestido de segredos, cabendo a um mestre os ensinamentos sagrados. A linguagem obscura e ininteligível freqüentemente empregada destinava-se a impedir que os não-iniciados tivessem acesso aos conhecimentos secretos, revelados apenas aos que eram considerados dignos de partilhá-los. 
No mundo ocidental a alquimia surgiu em Alexandria, em torno do século III A.C., fortemente apoiada na teoria grega dos quatro elementos e já estruturada como uma doutrina, o que faz com que os alexandrinos sejam considerados por alguns autores como os primeiros alquimistas verdadeiros. Para lá parecem ter convergido conhecimentos produzidos por diferentes povos da Antigüidade, como babilônicos, egípcios, caldeus, persas, judeus, gregos, e provavelmente chineses e hindus, mesclando o misticismo oriental ao racionalismo grego. Nessa confluência entre o Oriente e o Ocidente surgiram na época vários textos dedicados à Arte Sagrada da Alquimia, cuja autoria é atribuída a deuses, reis, ou a heróis míticos. Entre eles, o chamado Corpus Hermeticus, coleção de textos datados entre os séculos I e III da Era Cristã e atribuído a Hermes Trimegisto, o três vezes Grande, patrono do hermetismo e da alquimia (SCHURÉ, 1986).

mais importante desses textos, a Tábua de Esmeralda, estaria guardado segundo a tradição lendária, em Alexandria, condensando em poucas frases criptografadas, incompreensíveis para os não-iniciados, os principais preceitos alquímicos, tendo se tornado o compêndio da sabedoria hermética:

É verdadeiro, completo, claro e certo. $\bigcirc$ que está embaixo é como o que está em cima e o que está em cima é igual ao que está embaixo, para realizar os milagres de uma única coisa. Ao mesmo tempo, as coisas foram e vieram do Um, desse modo as coisas nasceram dessa coisa única por adoção.

O Sol é o pai, a lua a mãe, o vento o embalou em seu ventre, a Terra é sua ama; o Telesma do mundo está aqui. Seu poder não tem limites na Terra.

Separarás a Terra do Fogo, o sutil do espesso, docemente, com grande indústria.

Sobe da Terra para o céu e desce novamente à Terra e recolhe a força das coisas superiores e inferiores. Deste modo obterás a glória do mundo e as trevas se afastarão. É a força de toda força, pois vencerá a coisa sutil e penetrará na coisa espessa. Assim o mundo foi criado.

Esta é a fonte das admiráveis adaptações aqui indicadas. Por esta razão fui chamado de Hermes Trimegisto, pois possuo as três partes da filosofia universal. $\bigcirc$ que eu disse da Obra Solar é completo.

Do primeiro preceito foi extraído o princípio das correspondências, lei fundamental do ocultismo, que embasa a teoria do Macrocosmo e do Microcosmo e, por conseguinte, a astrologia, fundada na correspondência entre o homem e o cosmos, entendido como uma unidade cujas partes são interdependentes. Todas as coisas pertencem a um conjunto único e possuem com todo outro elemento deste conjunto relações necessárias, intencionais, não-temporais e não-espaciais (AMADOU, 1958), o que se tornou um princípio básico da alquimia.

A decadência dos mistérios da Antigüidade e a força da penetração da civilização grega em toda a região oriental da bacia do Mediterrâneo contribuíram para a realização da síntese religiosa greco-egípcia, da qual um dos resultados mais importantes e duráveis foi a formação do mito de Hermes Trimegisto, suporte definitivo do hermetismo.

Sob o império romano, os cultos aos mistérios helenísticos e às religiões orientais ganharam forte impulso e popularidade. Os filósofos de Alexandria, em um conjunto de movimentos filosófico-religiosos reunindo ciência e religião, promoveram um enxugamento do panteão. Foi criada uma genealogia para os deuses e segundo ela todos teriam tido origem no Egito.

Hermes, nessa síntese, corresponde ao deus egípcio Thot, "grande de magia", substituto de Ré, o deus supremo. Mestre de todas as ciências, personifica a revelação da sabedoria aos homens e do caminho da eternidade. 
Inventor das letras e dos números, da escrita e do cálculo, da geometria e da astronomia, guardião da magia escrita, é o escriba dos deuses. Intelecto deificado, sábio por excelência, é o deus do mistério e da arte de decifrá-lo. É a palavra que penetra até o fundo das consciências, conforme seu grau de abertura. Da mesma forma as representações simbólicas de Hermes imbricamse com as de Thot. Ele é o deus quádruplo, tetramorfo, dos quatro ventos do céu e dos quatro rostos. Esses atributos representam o conjunto dos conhecimentos vindos dos quatro pontos cardeais do horizonte e de todos os níveis da existência. Seu nome latino, Mercúrio, assim como seu sinal foram atribuídos pelos alquimistas ao metal que constituía a matéria-prima da Grande Obra, como assinalou Bertholet (1885).

De Alexandria a alquimia passou para Bizâncio e, no século VII, ao conquistarem a Pérsia e o Egito, os árabes tomaram contato com essa sabedoria. Os livros gregos foram traduzidos para o árabe e o Corpus Hermeticus difundiu-se pelo Islã, expandindo o culto a Hermes Trimegisto. A esse conhecimento, fruto do sincretismo greco-egípcio e judaico, foram somados saberes persas e sírios, de origem caldaica, e hindus, de origem budista.

Os árabes receberam esses conhecimentos antigos sobre a transmutação da matéria já prontos, com certeza, mas os retrabalharam e enriqueceram extraordinariamente, reinterpretando-os e remodelando-os à sua própria feição, particularmente o elixir da longa vida, seu interesse maior. A inexistência dessa substância na alquimia alexandrina sugere que pode ter havido um vínculo direto dos árabes com a China, de tal forma que podem ser reconhecidas duas fontes distintas para a alquimia árabe: uma greco-egípcia e outra sino-persa, tendo sido promovida uma síntese desses saberes.

A vertente mística, não obstante mantida, foi separada daquela que pode ser considerada como protoquímica e que veio a desenvolver os fundamentos do que se tornaria mais tarde a química moderna. Expandido, esse conhecimento foi introduzido na Europa ocidental com a dominação árabe na península lbérica, de tal forma que a alquimia européia nasceu igualmente pronta.

Traduzidos pelos árabes, antigos textos alquímicos penetraram na Europa no século XII, estimulando o desenvolvimento de uma alquimia medieval. Sobre esses textos debruçaram-se tradutores e compiladores da sabedoria islâmica, enciclopedistas, filósofos, estudiosos das ciências naturais que admitiam e acatavam os princípios alquímicos. Entre eles, Roger Bacon, que no século XIII entendia a alquimia como objeto de estudo da filosofia e propugnava uma "ciência experimental" ou, mais adequadamente, uma "ciência da experiência", fortemente atrelada ao experimentalismo da alquimia. Distinguindo uma "alquimia operativa" ou prática, de uma "alquimia especulativa" ou teórica, valorizava-a como auxiliar da medicina e como conhecimento prático para a investigação das ciências da natureza (GOLDFARB, 1987, p. 127-128).

No século XIV, devastada pela peste, por revoltas, invasões, guerras e distúrbios de diferentes naturezas, a Europa em crise, revalorizando o mundo antigo e suas tradições, deixou-se invadir por uma onda crescente de estudos alquímicos. Contra essa onda posicionou-se firmemente a lgreja Católica, reagindo não apenas à alquimia como um campo fértil para todo tipo de charlatanismo e impostura, alvo de oportunistas estimulados pela ambição, mas sobretudo ao grande interesse manifestado pelos segmentos mais esclarecidos, inclusive do próprio clero, o que provocava sua inquietação. Dominicanos e franciscanos 
publicaram vários decretos entre 1273 e 1323 proibindo estudos e práticas alquímicas, confirmados em 1317 por uma nova interdição lançada pelo Papa João XXII (GOLDFARB, 1987, p. 147).

Este clima de proibição e de perseguição, somado à crença de que ensinamentos elevados e conhecimentos mágicos, uma vez divulgados, vulgarizavam-se e assim perdiam sua força, intensificou a instituição do segredo, mantido sob forte juramento:

Eu te faço jurar pelos céus, pela terra, pela luz e pelas trevas.

Eu te faço jurar pelo fogo, pelo ar, pela terra e pela água.

Eu te faço jurar pelo mais alto dos céus, pelas profundezas da terra e pelo abismo do Tártaro.

Eu te faço jurar por Mercúrio e por Anubis, pelo rugido do dragão Kerkoruburus e pelo latido do Cão de três tetas, Cérbero, guardião do Inferno.

Eu te conjuro pelas três Parcas, pelas três fúrias e pela espada a não revelar a pessoa alguma nossas teorias e técnicas.

Com o Renascimento, a alquimia fundiu-se não apenas à medicina, com Villanova e Paracelso, entre outros, mesclando magia, medicina e alquimia, mas também às expressões artísticas, fertilizando-as extraordinariamente. A sofisticada simbologia alquímica foi incorporada à pintura, aos desenhos e gravuras, à arquitetura, música e literatura, tendo se configurado como uma das mais relevantes fontes inspiradoras da arte ocidental nos séculos XV e XVI.

Com o Renascimento floresceu um novo sistema de pensamento e uma nova concepção de cosmos. $\bigcirc$ mecanicismo impôs uma nova concepção de universo, ceifando um dos pilares da alquimia, a teoria das correspondências. Como demonstrou Goldfarb (1987), o vitalismo da alquimia perdeu terreno para o mecanicismo que prenunciava a construção de um novo pensamento científico.

Se em sua origem o hermetismo foi uma doutrina filosófica e literária, resultado de um longo esforço para conciliar as tradições egípcias, caldéias, e posteriormente gregas, ele acabou juntando noções e princípios muito diversos e rotulando doutrinas bastante heterogêneas, que tiveram em comum tão somente o esoterismo. Parte de um conjunto de tradições do mundo antigo sobreviveu ao longo da ldade Média e adentrou o Renascimento, miscigenando antigos saberes do Oriente e do Ocidente. Enquanto sua vertente racionalista deu origem à química moderna, a vertente mais propriamente filosófica acabou fragilizada pelos novos conhecimentos que tornaram anacrônica sua concepção e explanação da natureza, saindo ela finalmente de cena com o advento da ciência moderna. Na verdade ela não desapareceu de todo, e elementos vestigiais de sua face ocultista, mística, perduraram consideravelmente e ainda perduram em todo o mundo, até os tempos atuais, profundamente arraigados ao imaginário esotérico.

A Maçonaria, suas origens e fundamentos ${ }^{2}$

A Maçonaria se define ela mesma, desde o século XVIII, como um sistema peculiar de moralidade, fundado em alegorias e ilustrado por símbolos, com um
2. Em absoluto respeito à instituição dos segredos maçônicos, este texto expõe tão somente aspectos que são conhecidos entre nãoiniciados e que já foram tornados públicos em circunstâncias anteriores. 
caráter essencialmente iniciático (MELLOR, 1983, p. 18). Em princípio aberta a todos os homens livres e de bons costumes, de todas as crenças, religiões e nações (MAGISTER, 1935, p. 39), requer uma adesão profunda dos seus membros.

Não se considera a si mesma uma sociedade secreta, mas uma sociedade com segredos, que entende ser essa reserva necessária para evitar a vulgarização e a profanação de ensinamentos e valores muito elevados (CAMINO; CAMINO, [s.d.]). Entende que não segue dogmas, mas princípios imutáveis que constituem sua essência e seu espírito.

Esses princípios estão contidos nos chamados antigos deveres ou landmarks, ou seja, a demarcação dos limites, as leis fundamentais da Ordem Maçônica. São ao todo vinte e cinco, destacando-se dentre eles a crença no Grande Geômetra, o Grande Arquiteto do Universo, qualquer que seja a concepção teológica ou filosófica que se tenha dele. A crença na ressurreição e na vida futura. A presença fundamental de um Livro Sagrado, não importando qual seja, no altar do juramento nos templos maçônicos: Bíblia, Alcorão, Vedas, Torá, ou qualquer outro. $\bigcirc$ respeito à moral cívica, profissional e privada. $\bigcirc$ nivelamento, a igualdade absoluta e a fraternidade entre seus membros, exclusivamente do sexo masculino, que devem se apoiar mutuamente em caso de necessidade. A preservação da estrutura orgânica e simbólica da Ordem, o Grande Oriente, uma federação de lojas que trabalham com diferentes ritos, sob a direção de um Grão-Mestre, chefe da organização maçônica. A interdição à presença de profanos nas lojas. A divisão da Ordem em três graus sucessivos e hierárquicos, aprendizes, companheiros e mestres. A obrigação do segredo sobre os conhecimentos iniciáticos, selada sob juramento, e as formas de reconhecimento mútuo na circunstância do sigilo, como emblemas, sinais, toques, senhas e palavras sussurradas, pelos quais os maçons se reconhecem entre si e se distinguem dos demais, entre outros princípios (CAMINO; CAMINO, [s.d.]).

Fundando-se na geometria e na arte de edificar, pelas quais desenvolveu especial apreço, a Maçonaria construiu um vigoroso sistema de comunicação simbólica. Tanto da geometria quanto da arquitetura, que no sentido maçônico são associadas à construção espiritual, extraiu seus principais símbolos, intensamente utilizados na transmissão dos valores da Ordem.

Assim como ocorre com a Alquimia, suas origens, segundo manuais maçônicos, mergulham da mesma forma "na noite dos tempos, nas antiquíssimas primeiras civilizações, das quais se perderam os vestígios e a memória" (MAGISTER, 1934, p. 131. As narrativas mais fantasiosas entendem que Adão teria sido iniciado em todos os ritos da Maçonaria, o que simbolicamente recuaria a atividade da Ordem aos primórdios da humanidade, à mítica ldade de Ouro à qual se referem as tradições pagãs. Outras chegam mesmo a reconhecer que ela "iá existia antes da criação do mundo, espalhada entre os sistemas os mais variados do espaço" (OLIVER, 1823 apud ASLAN, 1959, p. 20).

Em 1909, Charles Bernardin, membro do Conselho da Ordem do Grande Oriente da França e do Grande Colégio dos Ritos, em sua obra Notes pour servir à l'histoire de la Franc-Maçonnerie à Nancy, identificou, examinando a literatura especializada, 39 opiniões distintas acerca da origem da Maçonaria (MELLOR, 1983, p. 13-15). Suas raízes estariam nos sobreviventes do dilúvio; no Egito Antigo; nas civilizações mesopotâmicas, mediterrâneas, ou do Extremo Oriente; entre os primeiros cristãos; nos construtores do Templo de Salomão, da Torre de Babel, das catedrais góticas; entre os Templários, germânicos e druidas; 
nos cruzados medievais, ou ainda na Escócia, na Inglaterra ou na França. Entendendo que sempre houve indivíduos movidos pelo ímpeto de penetrar no "mistério profundo das coisas", e que em diferentes tempos e lugares eles se organizaram em comunidades secretas, os mais entusiastas reconhecem nelas a presença da Maçonaria, tendo em vista que seus signos, símbolos e a essência das suas alegorias parecem remontar à Antigüidade.

Uma dessas versões, a que associa a Ordem aos construtores das catedrais góticas medievais, teve forte penetração (NAUDON, 1972). De acordo com ela, a Maçonaria descende das antigas corporações de mestres pedreiros formadas à sombra da lgreja na ldade Média, agregando os artífices ligados à construção que se reuniam para proteção mútua e defesa de seus direitos, daí advindo a designação de Maçonaria operária ou operativa. A estrutura tripartida, os mecanismos de progressão entre os graus, a estratégia defensiva do segredo, uma história lendária do ofício, uma tradição de fraternidade, moralidade e caridade, entre outros aspectos, são pontos em comum, sugerindo que de fato um teria derivado ou dado continuidade a outro.

Contudo, essa versão está longe de ser consensual, na medida em que, como frisa Dewar (1966), não há evidências inequívocas que demonstrem que os construtores medievais atribuíssem significado moral ao seu ofício e às suas ferramentas de trabalho. Neste caso, as semelhanças estruturais e organizacionais poderiam ser decorrentes do fato de a Maçonaria ter tão somente se inspirado no modelo bem sucedido das corporações de ofício medievais, sem que elas tenham sido necessariamente seu berço. De toda forma, os maçons modernos declaram que herdaram dos talhadores de pedra medievais uma organização com as mesmas características (estrutura tripartida, fraternidade e ajuda mútua, amparo a viúvas e descendentes, segredos e sinais reveladores, viagens constantes, etc.), reconhecendo-os como os criadores da Ordem e a si mesmos como seus continuadores.

Uma outra versão, contudo, que não exclui ou desqualifica a anterior, constitui na verdade seu principal mito de origem. Pouco importa, em nosso ponto de vista, se ela tem ou não fundamentos em dados da realidade, em vista da força simbólica que possui para a transmissão dos valores e ensinamentos da Ordem: a de que a Maçonaria surgiu durante a construção do Templo de Salomão (GOULD, 1896). Grande parte dos seus rituais deriva diretamente desse mito, revivido todo o tempo na cultura material, no cerimonial, nos ritos de iniciação e na ressurreição seguida de nova morte dos personagens envolvidos na trama dessa construção mitológica.

\section{A lenda de Hiram Abif e o Templo de Salomão}

Segundo a lenda, o templo foi concebido em nome da sabedoria e da iluminação espiritual por Salomão, filho de Davi e rei de Israel, símbolo maior dessas virtudes. Para erguê-lo em toda a sua magnificência, Hiram, rei de Tiro, não apenas forneceu a mão-de-obra e os materiais necessários, mas recomendou especialmente a Salomão o mestre de obras Hiram Abif, grande especialista em construção, homem justo e modelo de retidão, que se tornou o responsável pela realização e supervisão do trabalho. Os três juntos representam "os três grandes 
mestres que presidiram a construção concebida pela Sabedoria, realizada pela Força e dirigida pela Beleza, Ordem e Harmonia", tornando-a um modelo de perfeição, a mais perfeita expressão do Grande Arquiteto do Universo.

Artífices vieram de todos os cantos do mundo com diferentes graus de capacitação profissional e de talento individual. Por essa razão tornou-se necessário classificá-los em diferentes graus segundo suas competências, para melhor aproveitar o que de melhor cada um pudesse realizar. Hiram Abif os classificou em aprendizes, companheiros e mestres e deu a cada uma dessas categorias sinais, palavras e toques próprios para que se reconhecessem, tendo em vista que eles guardavam sob segredo, por proteção contra a concorrência, os conhecimentos de seus respectivos ofícios.

Toda a construção foi feita em silêncio, sem qualquer ruído de ferramentas de metal, já que o trabalho das pedras era feito externamente para que o barulho não profanasse o Templo, que tinha à frente duas grandes colunas de bronze. Durante os sete anos da sua construção reinou a paz e a prosperidade, até que perto de findar a obra três ambiciosos operários, julgando-se merecedores de serem promovidos a mestres, tentaram se apoderar à força dos seus sinais de reconhecimento. Ante a resistência de Hiram Abif, que respondia a eles recomendando "trabalhem e serão recompensados", eles o assassinaram a golpes respectivamente de régua, esquadro e malhete, e ocultaram seu corpo. Descoberto o crime, os restos de Hiram Abif foram sepultados e sua morte inviabilizou o fechamento da maior de todas as abóbadas do templo, aquela que mais devia agradar a Jeová, ficando a edificação portanto inacabada e imperfeita. Na mitologia maçônica esses três companheiros traidores são designados "por três nomes que a humanidade abomina e condena: a ignorância, irmã gêmea da vaidade; a hipocrisia, colaça da falsa amizade, e a ambição, aliada da violência e da improbidade" (LIMA, 1958, p. 292-293).

A lenda de Hiram, o primeiro dos operários do Grande Arquiteto que trabalham na Grande Obra de construção da natureza, tem um sentido fundador e sobre ela se construiu a Maçonaria. Seus elementos essenciais são respeitados e mantidos universalmente, em toda parte, em qualquer país. Há pequenas variações no mito, mas sua essência permanece a mesma, sendo ela que confere identidade à Maçonaria. Se porventura um rito tentar alterá-la, ele automaticamente deixa de ser maçônico.

A Maçonaria define o assassinato perpetrado contra o mestre de obras do Templo de Sálomão como a sua certidão de nascimento. Dele surgiram os sinais de reconhecimento e esse crime é continuamente revivido em seus rituais. Simbolicamente a Ordem discorre, através dele, sobre morte e ressurreição associadas à transmutação, à redenção que permite ressurgir para uma nova vida, no plano macrocósmico, microcósmico ou individual, e iniciático.

Na alquimia o fogo tortura a matéria, e desse sofrimento, que chega à morte, o metal sai regenerado. Simbolicamente, o mesmo ocorre nessa morte iniciática, da qual se ressuscita para um estado de sabedoria. O mito retoma portanto a associação alquímica entre ritual e sacrifício cruento, assumindo a premissa de que não há criação sem sacrifício prévio, presente em grande parte das religiões. Eliade (1979) relata, em diferentes culturas, os chamados sacrifícios de criação, gerados na crença de que a transferência de uma vida é necessária para a criação do novo. Tal como o êxito da obra metalúrgica exige a fusão/morte do metal, o sacrifício de uma vida humana é necessário para a transmutação espiritual. A morte iniciática conduz no caso à iluminação, à integração plena do ser ao Cosmos. 
A construção do templo evoca portanto um trabalho de criação exemplar e simboliza o grande esforço para alcançar a sabedoria, o ideal espiritual da perfeição, a aspiração à verdade e à virtude, só alcançáveis através de um intenso trabalho interior, com Salomão personificando esses atributos positivos.

O templo maçônico reproduz o Templo de Salomão (FOTOGRAFIA 3), imagem simbólica do Cosmos, e por essa razão suas dimensões são indefinidas: ele vai do Leste ao Oeste, do Norte ao Sul, do centro da Terra à abóbada celeste, ou seja, do Ocidente ao Oriente, do Setentrião ao Meio-Dia, de Nadir ao Zênite, dimensões simbólicas representadas pela cruz cardinal, a mesma que aparece no emblema dos cadinhos (LIGOU, 1974, p. 392). Posicionado em função do ritmo solar, ele se estende em direção à luz, tal como a mitologia maçônica menciona terem sido todos os templos da Antigüidade.

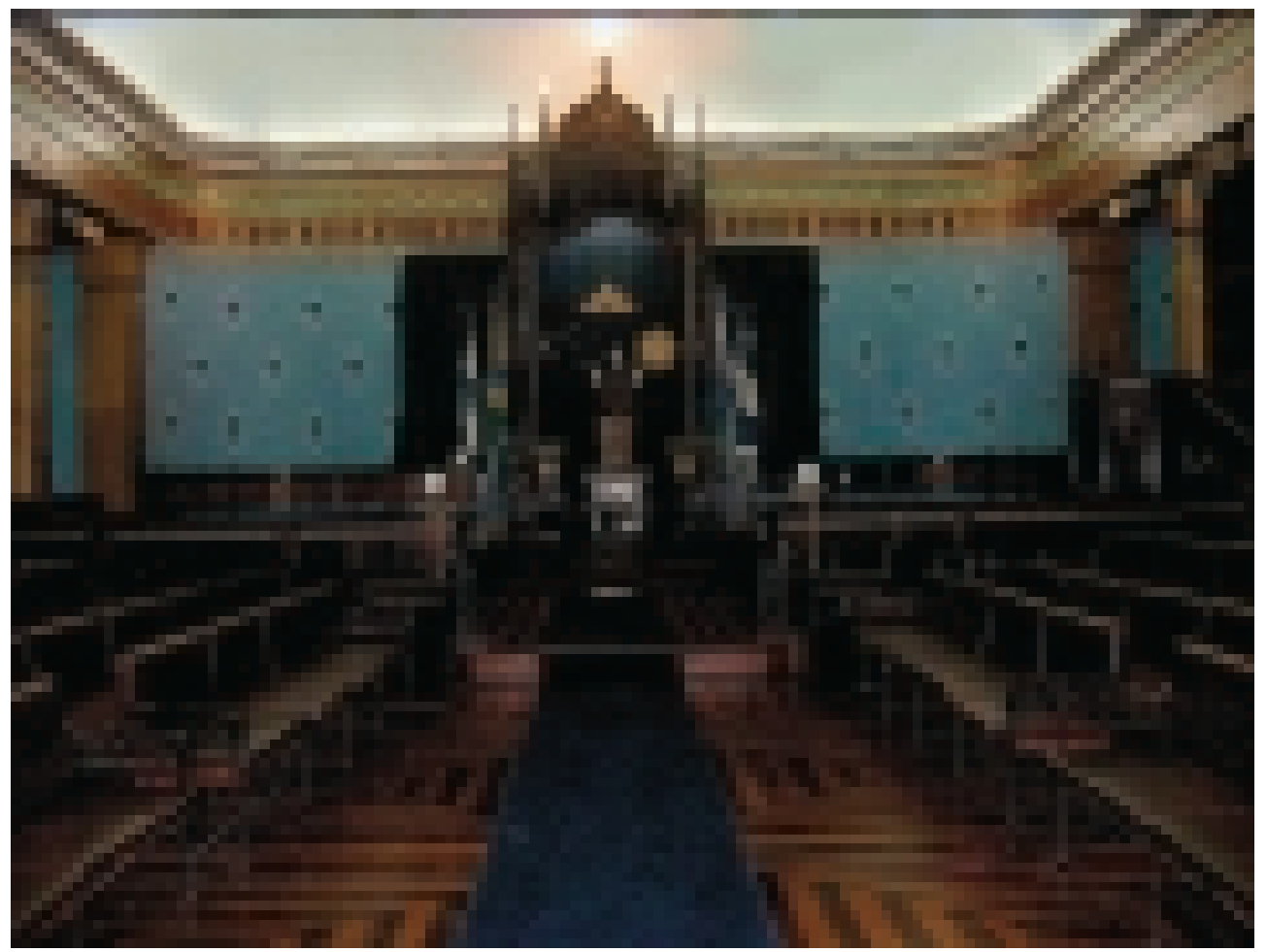

FOTOGRAFIA 3 - Templo Nobre do Palácio Maçônico do Lavradio, Grande Oriente do Estado do Rio de Janeiro. Fotografia de T. Andrade Lima.

Orientado no sentido Oeste/Leste, o templo se desloca com a Terra e vai ao encontro do Sol, da Luz. No plano simbólico, ele se move em direção à iluminação interior, sendo esta a razão da designação de Grande Oriente dada à federação de lojas maçônicas, palavra que designa o espaço sagrado, "fonte de toda a sabedoria, de toda força e de toda a beleza". $\bigcirc$ maçom sai do Nadir, 
lugar das trevas, recebe a luz do Oriente e continua sua elevação em direção ao Zênite, em direção à perfeição (LIGOU, 1974, p. 393-396).

Em todos os rituais maçônicos as trevas se opõem à luz, o profano está na sombra e aspira à claridade. Nos ritos tradicionais a abertura dos trabalhos simboliza a passagem do crepúsculo à aurora, com a iluminação gradual do templo. No Aurora consurgens, texto alquímico atribuído a Santo Tomás de Aquino, a sabedoria surge com o raiar do dia, com a "hora de ouro", com a passagem da escuridão da noite para a claridade do dia, associada ao ouro.

Representado por um quadrilongo, imagem do templo perfeito, seu teto é em forma de abóbada. Sempre recoberta de estrelas, essa abóboda simboliza o Cosmos. As duas colunas do seu pórtico (FOTOGRAFIA 4), as colunas de Salomão, erguidas por Hiram Abif e designadas respectivamente como Jakin (U) e Boaz (B), estão a oeste, ao sol poente. Em oposição a elas, a oriente, está o trono de Salomão (FOTOGRAFIA 5), onde assenta o Venerável Grão Mestre com as costas voltadas para o sol nascente, ladeado pelos seus dois Vigilantes, Hiram, rei de Tiro, e Hiram Abif. $\bigcirc$ termo que designa o Venerável, no vocabulário maçônico, é Enxofre; o Primeiro Vigilante, Mercúrio; o Segundo Vigilante, Sal; o Orador é o Fogo; o Secretário, o Ar; o Hospitaleiro, a Água; e o Tesoureiro, a Terra. Ou seja, os três princípios e os quatro elementos dos alquimistas nomeiam os pilares da Ordem.

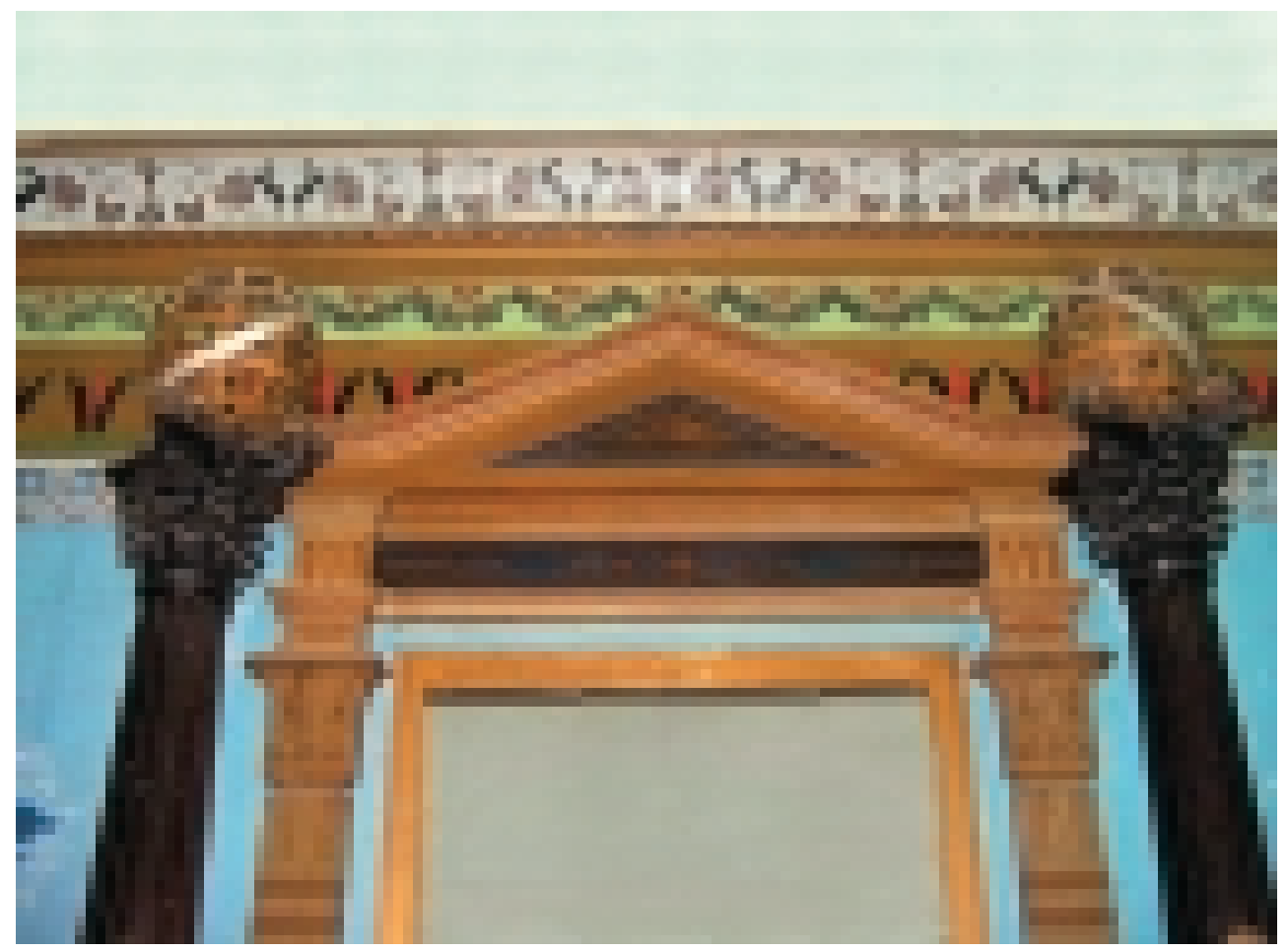

FOTOGRAFIA 4 - Portal do Templo Nobre do Palácio Maçônico do Lavradio, Grande Oriente do Estado do Rio de Janeiro. Fotografia de T. Andrade Lima. 


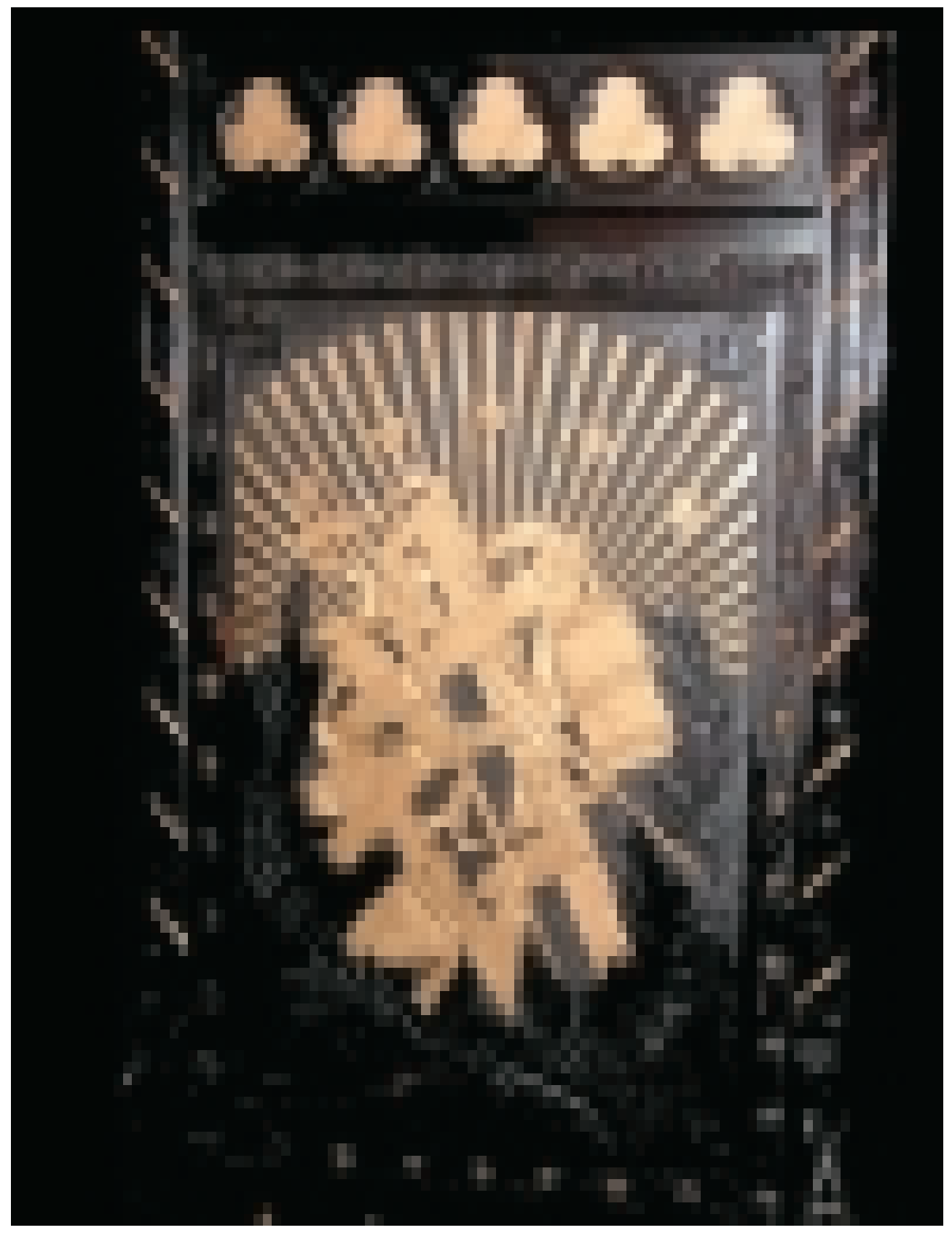

FOTOGRAFIA 5 - Espaldar do trono dos Veneráveis Grãos-Mestres que presidem as sessões ritualísticas no altar do Templo Nobre, dourado com a simbologia maçônica, Grande Oriente do Estado do Rio de Janeiro. Fotografia de T. Andrade Lima. 
Atrás e acima do trono de Salomão figura o delta luminoso com o Grande Olho, o olho divino que tudo vê, o triângulo que aparece no Oriente (FOTOGRAFIA 6). É o Verbo, o Logos, o Princípio Criador, o Grande Arquiteto do Universo, é a vigilância incessante do Grande Inspetor, que tudo criou e a tudo preside.

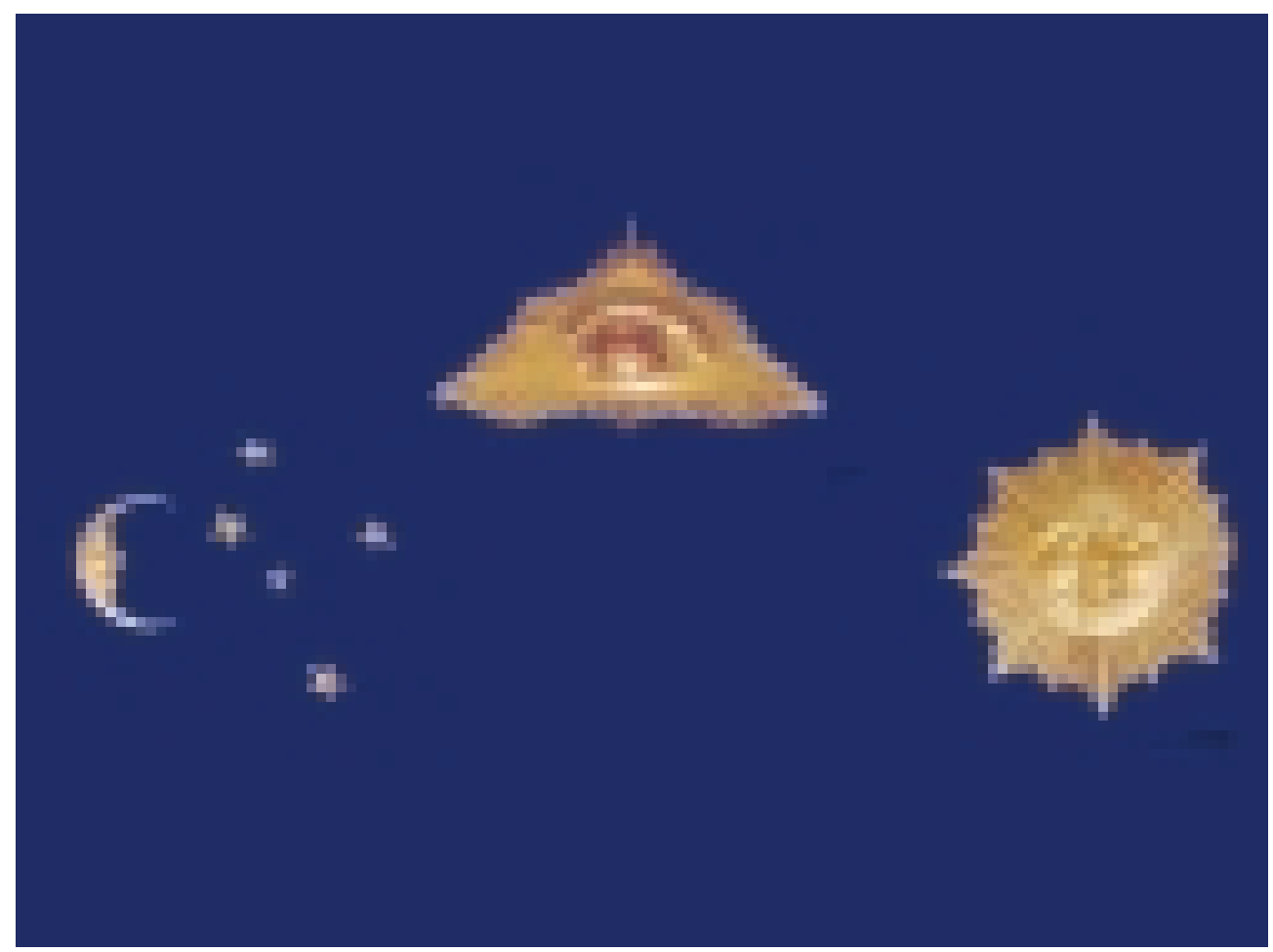

FOTOGRAFIA 6 - Painel do altar do Templo Nobre, em dourado, com o delta luminoso, o Grande Olho, entre o Sol e a Lua, Grande Oriente do Estado do Rio de Janeiro. Fotografia de T. Andrade Lima.

O Grande Olho está colocado entre o Sol e a Lua, que correspondem ao olho direito e esquerdo do "Homem Universal", identificado ao Macrocosmo. Não é nem o esquerdo, nem o direito, mas um terceiro olho. A Lua / olho esquerdo corresponde ao tempo passado, o Sol / olho direito ao tempo futuro, e o terceiro olho ao presente, isto é, ao instante indivisível que, entre o passado e o futuro, é como que um reflexo da eternidade no tempo (GUÉNON, 1993, p. 385).

É no templo que são desenvolvidos os ritos maçônicos, inspirados diretamente nas técnicas construtivas dos artífices do Templo de Salomão. Nas oficinas das lojas os maçons trabalham com seus utensílios e o avental de seu respectivo grau, símbolo do trabalho operário (CARVALHO, 1997). Da mesma forma que os obreiros construíram o Templo de Salomão com as ferramentas próprias de seus ofícios, os maçons devem promover a Grande Obra de sua 
construção espiritual com ferramentas simbólicas, que constituem a base da iniciação maçônica.

Os construtores do Templo de Salomão e suas ferramentas

Na sua trajetória iniciática, os recém-chegados começam lavrando a pedra bruta (FOTOGRAFIA 7) e gradativamente prosseguem no desenvolvimento de suas habilidades até que consigam produzir a pedra polida (FOTOGRAFIA 8), perfeita para a construção. $\bigcirc$ cubo, a pedra cúbica, símbolo de elevação moral, corresponde à pedra filosofal da construção espiritual, que constitui a, Grande Obra, o aperfeiçoamento individual que conduz a um estado superior. É o único sólido que pelo paralelismo e a retidão de suas faces pode ser bem aproveitado na construção do Edifício Social, daí sua importância no simbolismo maçônico. Representa o Mestre, o ideal de perfeição humana.

Nessa operação são utilizadas nove ferramentas, ativas e passivas, consideradas essenciais: esquadro e compasso, cinzel e malhete, nível e prumo, régua, alavanca e colher de pedreiro.

Entre as ferramentas ativas, que simbolizam o espírito, estão o compasso, o malhete, o prumo e a régua. Entre as passivas, que simbolizam a matéria, estão o esquadro, o nível, o cinzel e a alavanca. A colher de pedreiro é considerada uma ferramenta neutra.
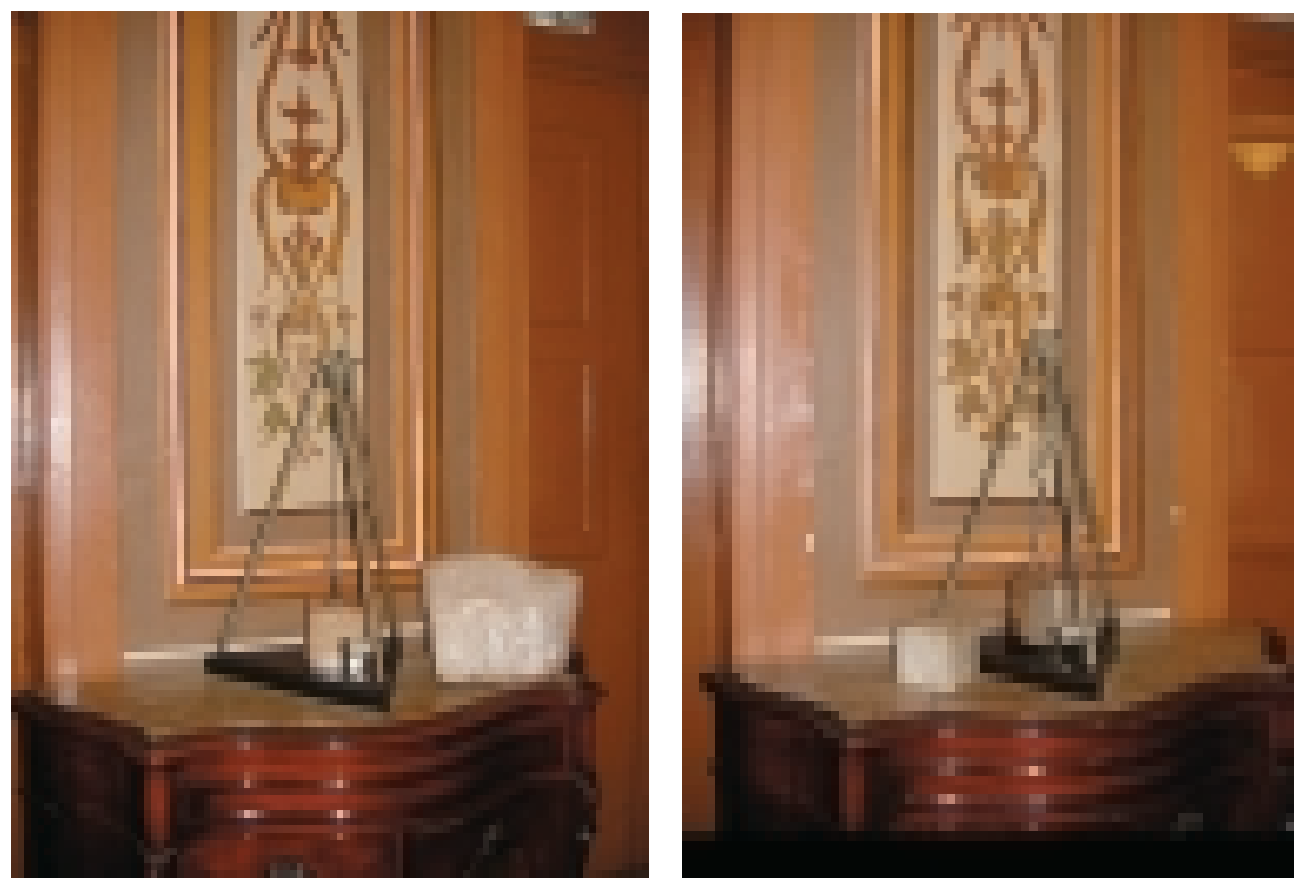

FOTOGRAFIAS 7 e 8 - A pedra bruta e a pedra lavrada, Sala de Reuniões do Conselho do Grande Oriente do Rio de Janeiro. Fotografia de T. Andrade Lima. 
O profano, ao receber a Luz, torna-se aprendiz. Sua tarefa primordial, tal como os talhadores de pedras do Templo de Salomão, é lavrar a pedra bruta e para isso bastam o cinzel e o malhete. A pedra bruta é o caos, simboliza as imperfeições humanas e deve ser lavrada a partir de um trabalho interior constante. Desenvolvida essa habilidade, ele se torna um companheiro e passa a trabalhar a pedra com vistas a aprimorar sua forma e a promover seu polimento, mediante o uso de novas ferramentas, que aprende a utilizar ao longo de cinco viagens de iniciação. Nesta etapa ele deve se aperfeiçoar como artífice. $\bigcirc$ processo de lavrar a pedra bruta corresponde à Grande Obra alquímica e conduz à percepção da organização do mundo pelo Criador.

Na primeira viagem, o cinzel e o malhete o remetem ao período de aprendizado. Na segunda, o esquadro - que serve para dispor corretamente os materiais - e o compasso, que serve para medidas exatas, simbolizam os conhecimentos geométricos indispensáveis para a edificação de uma obra. $\mathrm{Na}$ terceira, a régua e a alavanca são necessárias para colocar no lugar correto os materiais da construção. Na quarta, o prumo e o nível são também necessários para uma correta edificação. Na quinta e última viagem, aquele que se aperfeiçoa recebe a colher de pedreiro, a ferramenta que dá o acabamento a uma construção, significando a perfeição do trabalho e a sua glorificação.

Cada uma dessas ferramentas utilizadas nos ritos iniciáticos tem um simbolismo. O compasso, sempre associado ao esquadro, é o símbolo universal da Harmonia, do espírito, das possibilidades do conhecimento, dos limites estritos nos quais o maçom deve se manter. Sempre utilizado nas iniciações, é o instrumento da medida exata. Assume diferentes posições em relação ao esquadro, dependendo do grau no qual é representado: no grau de Aprendiz, ele fica sob o esquadro, já que a matéria ainda domina o espírito; no grau de Companheiro, ele fica cruzado com o esquadro, mostrando que matéria e espírito se equilibram; no grau de Mestre, ele fica sobre o esquadro, pois aí o espírito se sobrepõe à matéria. Já o esquadro traça ângulos retos, reúne o horizontal e o perpendicular, concilia os contrários. Simboliza a retidão moral.

O cinzel, utilizado na escultura, na arquitetura, nas belas artes, não tem nenhuma utilidade se dissociado do malhete, com o qual é golpeado. Sua função é desbastar, lavrar a pedra bruta. É utilizado no trabalho de eliminar defeitos e imperfeições no longo e áspero caminho do auto-aperfeiçoamento. $\bigcirc$ malhete, martelo de duas cabeças em madeira que o golpeia, o Tau dos antigos iniciados, simboliza a firmeza e a perseverança, a autoridade e o comando. Abre e fecha os trabalhos na loja, dá ordem de silêncio.

O nível, sempre associado ao prumo, é o utensílio que reconhece se um plano é horizontal e determina diferenças de altura. Na Maçonaria é representado por um triângulo, na verdade um esquadro, em cujo topo está fixado um fio de chumbo ou prumo. O nível indica o horizontal, mas é munido da vertical, o prumo, que evita o desvio oblíquo e permite verificar a perpendicularidade, compondo desta forma um instrumento mais completo. Se o nível simboliza a igualdade social, base do direito natural, do direito dos homens à vida, à instrução, à felicidade, à justiça, o prumo simboliza a retidão, o equilíbrio. Através dele ficam visíveis os erros e as imperfeições, que podem ser então corrigidos. É um utensílio fundamental para a correta edificação de uma obra, para o aperfeiçoamento do maçom. 
A régua, sempre associada à alavanca, traça linhas retas que podem ser estendidas ao infinito, é o emblema da retidão inflexível da lei moral, símbolo do dever maçônico, do relativo, do infinito, porque a linha reta que ela permite construir não tem começo nem fim. Necessária ao acabamento de uma Obra, ela permite a precisão na execução, verifica os alinhamentos, para que seja obtido um conjunto homogêneo e coerente. A alavanca que a acompanha simboliza o poder da inteligência, da vontade e da razão.

A colher de pedreiro alisa as superfícies, arremata o trabalho. É o símbolo do amor fraternal que une todos os maçons, espalha o cimento utilizado na construção da Grande Obra, emblema das qualidades essenciais que eles devem possuir.

Há ainda inúmeros outros símbolos que aparecem na arquitetura, em painéis, estandartes, escudos, bordados sobre panos e tapetes, etc. Entre eles, o pavimento em xadrez preto e branco, emblema da igualdade, independentemente da cor da pele; a ampulheta, símbolo da vida efêmera; a escada de Jacó, que simboliza os graus que o maçom deve galgar, um a um, até chegar ao topo; as janelas, relacionadas ao simbolismo solar, e, em última instância, à iluminação interior; a corda dos 81 nós, cadeia de união cujos nós entrelaçados simbolizam a união fraternal que liga todos os maçons do globo, arrematada nas suas quatro extremidades por borlas, que significam o agrupamento de irmãos para o trabalho; o pelicano, emblema do amor pelo próximo, pela humanidade. Generoso até o sacrifício, o pelicano armazena alimentos em uma bolsa, onde eles são digeridos e regurgitados mediante uma compressão com o bico, para a alimentação dos filhotes.

Todo esse repertório de símbolos é utilizado didaticamente nos painéis próprios de cada grau, que são afixados nas lojas por ocasião das sessões: o painel de aprendiz (FOTOGRAFIA 9), o de companheiro (FOTOGRAFIA 10), o de mestre, cada um exibindo os símbolos adequados à respectiva categoria. Eles revivem a prancheta onde Hiram Abif desenhava seus projetos e, simbolizando o planejamento, devem induzir à reflexão.

\section{A liturgia maçônica}

Na topografia maçônica do Cosmos é mantida a distinção igualmente tripartida em céu, terra e inferno. Essas três grandes regiões podem ser atravessadas sucessivamente porque estão interligadas por um eixo vertical, símbolo cósmico de passagem. O processo iniciático é o que possibilita esse trânsito e a elevação de um nível ao outro ao longo desse eixo, de aprendiz a companheiro e de companheiro a mestre.

Essa progressão é feita através de ritos de passagem que consistem em ultrapassar simbolicamente quatro provas de superação dos quatro elementos alquímicos: fogo, ar, água e terra, ao longo de uma viagem que conduz da terra aos céus, após uma descida aos infernos. $\bigcirc$ iniciante toma contato com os quatro elementos, entra em confronto com eles, e enquanto luta é um Aprendiz. Ao vencê-los purifica-se e finalmente vê a Luz, tornando-se Companheiro, em uma ritualística de origem claramente hermética, com raízes mais fundas no mundo antigo. Neste combate, a cultura vence a natureza. 


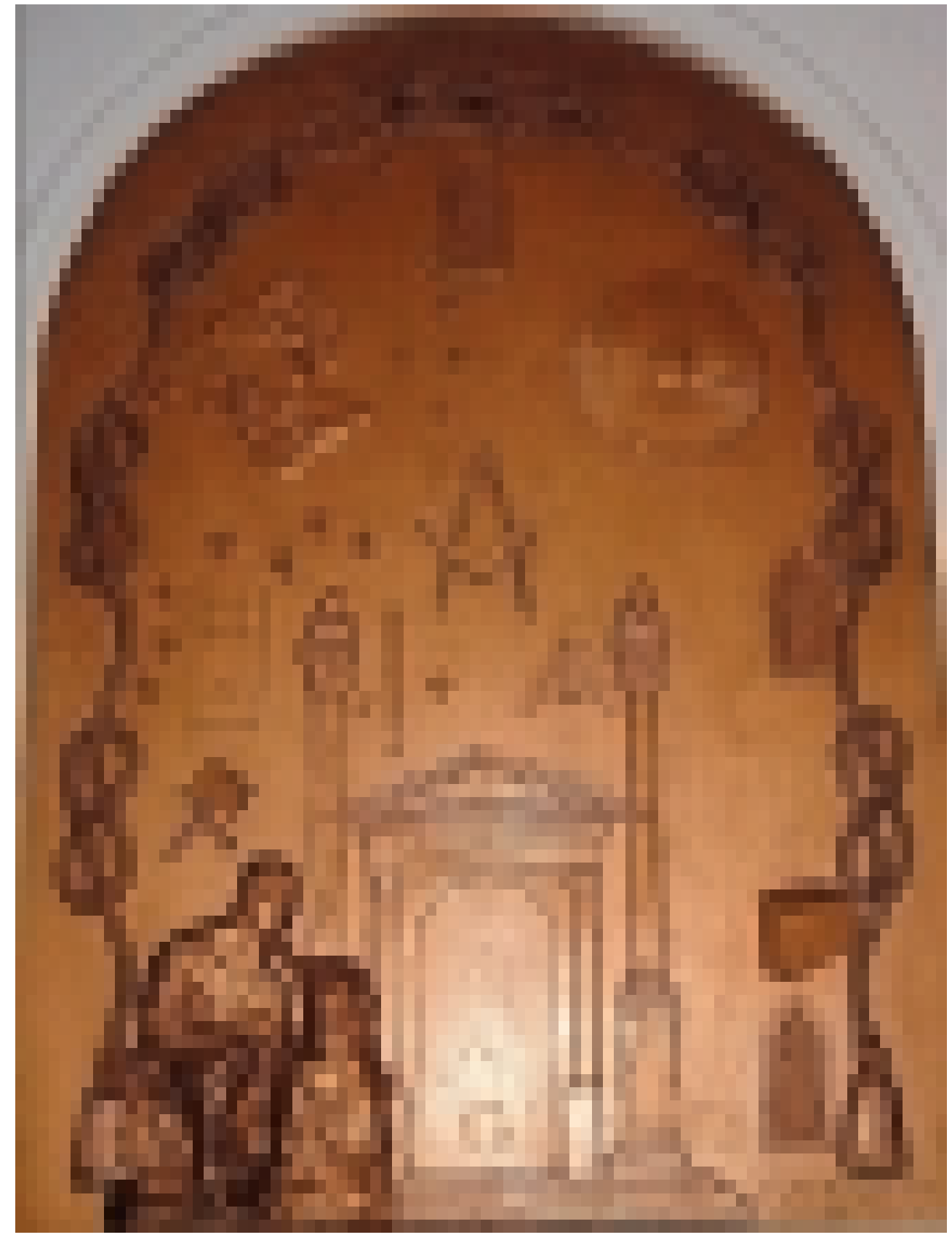

FOTOGRAFIA 9 - O Painel do Aprendiz, em dourado, com os símbolos de seu respectivo grau. Em primeiro plano, o iniciante lavra a pedra bruta junto ao portal do Templo de Salomão. Palácio Maçônico do Lavradio, Grande Oriente do Estado do Rio de Janeiro. Fotografia de T. Andrade Lima. 


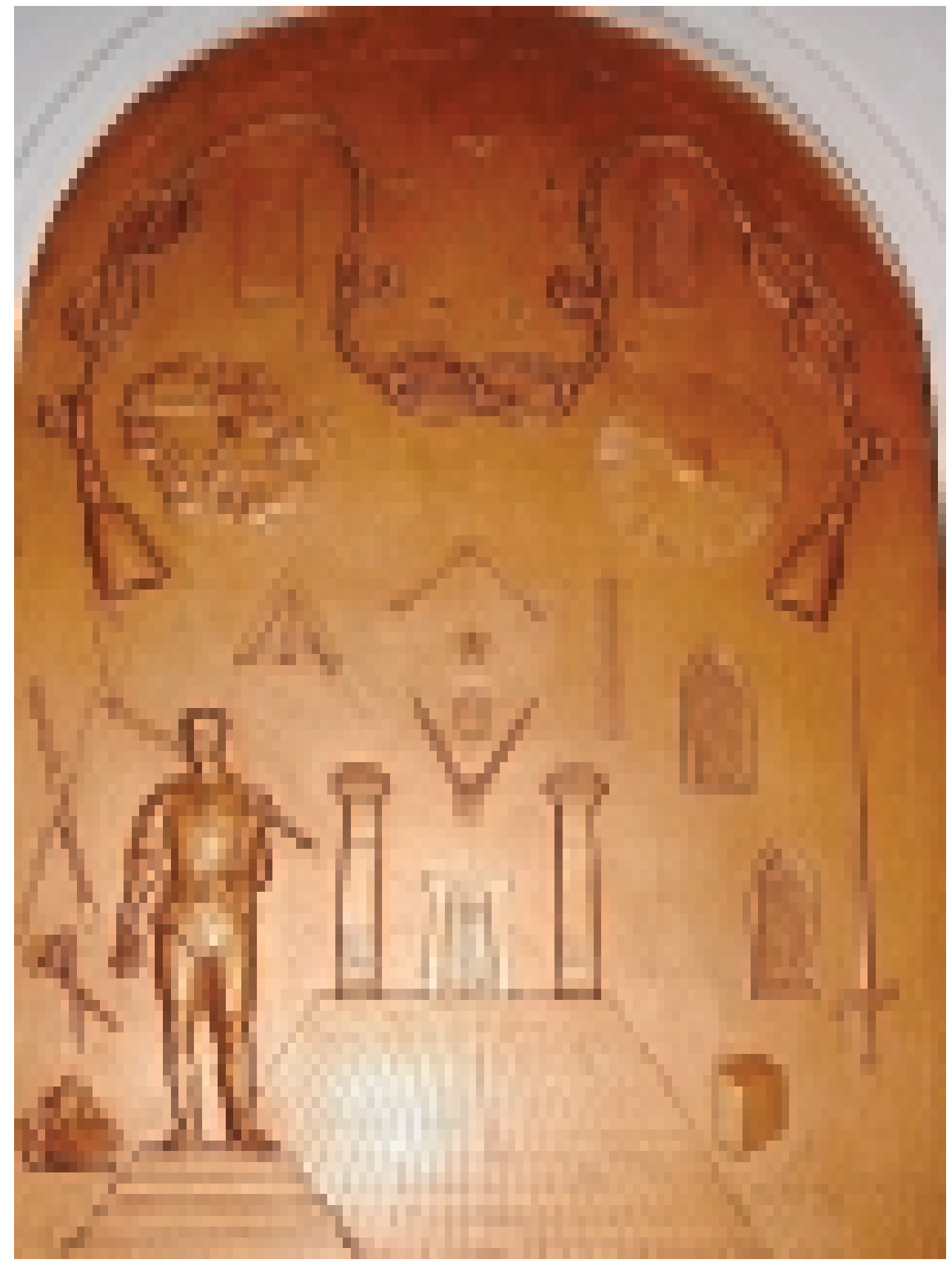

FOTOGRAFIA 10 - O Painel do Companheiro, em dourado, com os símbolos do seu respectivo grau, já tendo lavrado a pedra. Palácio Maçônico do Lavradio, Grande Oriente do Estado do Rio de Janeiro. Fotografia de T. Andrade Lima. 
Inicialmente o candidato fica recluso na Câmara de Reflexão, que corresponde ao ovo filosofal dos alquimistas, um local fechado, silencioso e sem iluminação como uma caverna, símbolo das trevas, do túmulo, onde a putrefação prepara a germinação, ou seja, o segundo nascimento (CASTELLANI, 1987a; LIGOU, 1974, p. 395). São colocados ante seus olhos os príncípios alquímicos: o enxofre, ativo, energia expansiva, símbolo do espírito, e o sal, símbolo da sabedoria e da ciência, excluindo-se o mercúrio, força centrípeta que se opõe ao enxofre, na medida em que o iniciado deve ficar livre das influências "mercuriais" nessa etapa liminar da iniciação.

O primeiro elemento que ele encontra é portanto a terra, o domínio subterrâneo das suas entranhas, onde se desenvolvem tanto germes quanto sementes. Da terra ele sai e faz a sua viagem aos ares, sendo purificado por eles, cujo sopro impetuoso varre suas teorias pessoais; segue-se a água, que no batismo filosófico elimina suas impurezas; e finalmente o fogo, na quarta e última viagem em que tem que vencer uma tripla linha de chamas, o que o permite contemplar os infernos, ou seja, a verdade que se esconde dentro de si mesmo. Nessas viagens ele se distancia do mundo profano, se integra ao sagrado e, uma vez purificado pelos elementos, recebe a iluminação.

A liturgia maçônica segue inúmeros e diferentes ritos, ramos particulares da Ordem que se distinguem dos demais exclusivamente pela forma, como o Escocês Retificado, Escocês Antigo e Aceito, Emulação, Adoniramita, Schroeder, York, Moderno, entre outros (CASTELLANI, 1987b,c), alguns com abrangência mundial, outros de caráter mais local, mas sempre protegidos pelo segredo.

Um dos mais antigos, com uma considerável profundidade temporal e universalmente difundido é o Rito Escocês Antigo e Aceito, que respeita as mais antigas tradições da Ordem e por essa razão foi tomado como rito de referência nesta investigação. Impregnado de hermetismo e simbólico por excelência, apresenta, além dos três graus habituais - 1 a 3, Aprendiz, Companheiro, Mestre - o chamado fenômeno dos Altos Graus, do 4ํa a 33ํ․ Estes são graus filosóficos, não devem obediência ao Grande Oriente e sim às oficinas de ritos.

O segredo é uma obrigação assumida no momento em que os candidatos aderem à Maçonaria, jurando nada revelar a profanos. No entanto, para que possam se reconhecer uns aos outros, recorrem a símbolos e a todo um gestual codificado que sinaliza o pertencimento à Ordem, sem que os não-iniciados percebam (DUBREUIL, 1838, p. 51).

A instituição do segredo caracteriza a atividade da Maçonaria e ele é exigido em três níveis: 1) o segredo do pertencimento à Ordem, não só como proteção às hostilidades dos não-maçons, mas para que no nível das preocupações profanas não se suponha que exista socialmente, entre os maçons, posicionamentos e atitudes comuns a seus membros, que só existem intramuros. Isto thes assegura a liberdade de expressão, inclusive política, perante a sociedade, sem que suas posições sejam creditadas ao fato de pertencerem à Ordem. Irmãos que se destacam por suas posições na sociedade ficam resguardados, por exemplo, de solicitações abusivas, pedidos inconvenientes, e assim por diante. 2) $\bigcirc$ segredo dos ritos, que se estende naturalmente aos símbolos, por se tratar de provas a serem vencidas nas diferentes etapas de aperfeiçoamento espiritual e sobre as quais os candidatos não devem ter conhecimento prévio. 3) $\bigcirc$ segredo das deliberações, o que garante a sua liberdade interior, condição essencial do trabalho de aperfeiçoamento maçônico, 
tal como ocorre em profissões que mantêm segredo profissional, como médicos, advogados e sacerdotes (LIGOU, 1974, p. 1203-1204).

A exigência do segredo é antiga na trajetória da humanidade, aparecendo desde tempos muito recuados na reserva e proteção tanto de práticas mágico-religiosas quanto de técnicas e, mais tarde, tanto entre alquimistas quanto entre artífices medievais. Entre os maçons ele é considerado reminiscência dos segredos de ofício, tendo se tornado particularmente necessário, na história da Maçonaria, em tempos de perseguição. Aquele que revela os segredos da Ordem é considerado um traidor, um desonrado, merecedor de desprezo por não ter cumprido um compromisso solene, feito sob juramento.

Para viabilizar a comunicação diante da obrigação do segredo, foram criadas formas particulares de toque, criptografias, sinais identificadores, etc. A "palavra semestral", por exemplo, foi instituída em 1773 pelo duque de Orleans, tratando-se de uma senha periodicamente renovada e transmitida apenas de forma oral, de ouvido a ouvido, sussurrada com a maior discrição possível ICAMINO; CAMINO, [s.d.]), com o objetivo de impedir o acesso de não-maçons às reuniões dos iniciados.

A instituição do segredo foi a responsável pela aura de mistério que sempre cercou e ainda cerca a Maçonaria, espicaçando a curiosidade dos nãomaçons. Essa aura lhe conferiu poder através dos tempos, real em alguns momentos, imaginário em outros, mas sempre sustentando-a como um poder paralelo. $\bigcirc$ mistério precisa ser mantido para que a Maçonaria sobreviva na atualidade, ainda que a instituição não sofra mais qualquer tipo de perseguição, ou ela se expõe ao risco do seu completo esvaziamento.

\section{desenvolvimento histórico da Maçonaria}

Abstraindo as narrativas lendárias, as evidências mais concretas apontam para o surgimento da Maçonaria na Escócia, de onde teria alcançado a Inglaterra e passado para o continente, dispersando-se por toda a Europa (para essa trajetória ver FINDEL, 1866). Até o século XIV aparentemente não há sinais efetivos de que a Maçonaria esteja organizada, e, ao historiá-la, Mellor (1983) reconhece três fases em sua trajetória:

- período operário, quando a Maçonaria era uma fraternidade voltada tãosomente para os que trabalhavam na construção de edifícios;

- período de transição, entre a era elizabetana e 1717, quando se esboçou uma mudança nas suas estruturas, sobretudo na Escócia, Irlanda e Inglaterra. Provavelmente para contornar a falta de recursos, as lojas operativas começaram a aceitar estranhos ao ofício da construção como membros honorários, entre eles nobres, mecenas, intelectuais, filósofos, etc., que passaram a ser designados como maçons aceitos. De início pouco expressivos, mais interessados na teoria que na prática, eles se expandiram numericamente de uma tal forma que suplantaram os profissionais dos ofícios construtivos, nascendo então uma nova Maçonaria, constituída quase que exclusivamente por aceitos;

- período especulativo, inaugurado em 1717, com a reforma filosófica e a constituição da primeira Grande Loja da Inglaterra, fruto da fusão de quatro 
antigas lojas londrinas $(\mathrm{ACOB}, 1981$ ). Consolidou-se a Maçonaria moderna, designada como especulativa ou filosófica, em contraposição à operária, expandindo-se extraordinariamente pelos dois hemisférios.

fenômeno da aceitação, ou seja, da admissão de indivíduos que não trabalhavam diretamente nas construções como operários, fez nascer na GrãBretanha as lojas especulativas. Esse termo apareceu pela primeira vez no chamado manuscrito Coke, designando a teoria, o conhecimento teórico da construção, em oposição à sua prática, tal como na alquimia. Os maçons qualificados como especulativos passaram a valorizar mais a geometria que a prática em si dos ofícios, transformados em metáforas para essa vertente intelectual da Ordem. $\bigcirc$ interesse pela construção propriamente dita foi substituído por uma perspectiva alegórica e fortemente simbólica da arquitetura, visando à construção perfeita não mais de prédios, mas do ser humano, a Grande Obra, metaforizada no Templo de Salomão.

Daí em diante a Maçonaria fragmentou-se claramente em duas tendências: em uma delas, diminuiu o interesse pelos símbolos, em virtude de um crescente racionalismo; seus rituais foram laicizados e esvaziados de tudo o que pudesse sugerir espiritualidade. Já a outra, pelo contrário, passou a se apoiar fortemente no hermetismo, no simbolismo e no esoterismo.

Provavelmente essa vertente esotérica acentuou-se com a admissão de alquimistas, hermetistas e cabalistas entre os aceitos, de tal forma que no século XVIII o ocultismo penetrou profundamente na Maçonaria (MELLOR, 1983, p. 177). Essa fusão sem dúvida contribuiu para que os ritualistas do século XVIII se inspirassem em tratados alquímicos para a construção das suas alegorias, introduzindo elementos da alquimia na iniciação maçônica. Necessitando de um abrigo contra a intolerância católica e protestante, alvos permanentes da Inquisição, eles foram acolhidos pela Ordem, que passou a iniciar e proteger os que se dedicavam ao estudo das ciências ocultas, sendo ela mesma perseguida pela lgreja e fortemente cerceada por sucessivas bulas e encíclicas papais (Clemente XII, 1738; Benedito XIV, 1751; Pio VI, 1775; Pio VII, 1821; Leão XII, 1825; Pio VIII, 1829; Gregório XVI, 1832; Pio IX, 1846; Leão XIII, 1884).

A intensidade e o ritmo dessas sucessivas condenações atesta a força da penetração da Maçonaria, e o período mais intenso em que essas proibições foram lançadas, compreendido na seqüência de datas acima, corresponde ao período de seu florescimento máximo. Considerando-a incompatível com a religião cristã, a lgreja ameaçava com a pena da excomunhão os católicos que, respondendo ao ativo recrutamento da organização, se filiassem a ela. Vieira (1981) chamou a atenção para o fato de que a defesa da liberdade de culto e da "liberdade de consciência" defendida pelos maçons sempre foi, na verdade, uma defesa em causa própria.

Nessa longa transição da vertente operária para a especulativa, entre os séculos XV e XVIII, muitos maçons operários se transformaram em aceitos, distribuídos em três classes de lojas: as puramente operárias, as operárias que incorporavam alguns aceitos, e as totalmente especulativas, tendo afinal estas últimas se tornado absolutas com o desaparecimento das demais.

A progressiva decadência das corporações de ofício pode ter contribuído consideravelmente para o esvaziamento da Maçonaria operária. Da mesma forma as doutrinas esotéricas, subterrâneas na ldade Média, vieram impetuosamente à tona no século XVIII, o que ajuda a explicar o florescimento da 
vertente especulativa nesse período. As causas da notável expansão da Ordem Maçônica no século XVIII, que veio a acumular impressionante poder político também pelo século XIX adentro, ainda não estão suficientemente explicadas e estão por merecer uma maior atenção dos historiadores.

simbolismo hermético dos cadinhos

Somente um dos emblemas encontrados nos cadinhos da Casa da Moeda do Rio de Janeiro, aquele que aparece associado às iniciais IS (FIGURA 1-j), pôde ser identificado. McMurtrie (1938, p. 297-298) o reproduziu ao discutir marcas de impressores, atribuindo-o a John Siberch, o primeiro impressor de Cambridge (FIGURA 5). Esta marca foi aposta à obra de Galeno De temperamentis, por volta de 1521, o primeiro livro impresso por Siberch.

É notável a perduração desse emblema até o século XVIII, o que pode ser atribuído tanto a herdeiros que mantiveram sucessivamente a marca de seus antecessores, como era habitual à época, quanto a uma revivescência simbólica, por razões desconhecidas. Esta última possibilidade parece a mais provável, já que praticamente não há diferenças entre o emblema do século XVI e o do XVIII, senão o menor porte das iniciais na forma original, quando, pelo contrário, sucessores costumavam promover pequenas alterações que sinalizavam a nova titularidade.

Nesse sentido, as pequenas variações existentes em cada uma das três categorias de marcas encontradas na base dos cadinhos (FIGURA 1 ) são por nós interpretadas como alterações feitas por herdeiros e sucessores (ver exemplo na FIGURA 3, nos 22 e 23), e o número de variantes nas três categorias sugere que elas perduraram consideravelmente.

Do ponto de vista da origem, o emblema de John Siberch sugere uma proveniência inglesa para os cadinhos que aparecem no Brasil, o que não é improvável, tendo em vista que a Inglaterra os produziu. De toda forma, deve ser relembrada a referência de Eschewege sobre a proveniência boêmia desses objetos no século XIX, mencionada no início deste texto, além da alemã. Boschi (1986, p. 31 ) inclusive relata a sugestiva existência de entidades místicas na Boêmia e na Hungria, designadas como "Amigos da Cruz" ou "Irmãos da Cruz".

A presença de um mesmo emblema em um livro do século XVI e em cadinhos do século XVIIII atesta a estreita ligação entre livreiros e impressores e outros ofícios ao longo de pelo menos dois séculos. Contudo, não foram encontradas maiores informações capazes de permitir um entendimento melhor das razões pelas quais a marca de John Siberch, especificamente, foi utilizada dois séculos depois por fabricantes de cadinhos do século XVIII.

Embora esmagadoramente ocorrente entre livreiros e impressores dos séculos XVI e XVII, o signo que associa o algarismo 4 a uma cruz dupla é comum a inúmeras outras categorias profissionais, o que nos obriga a descartar a hipótese de se tratar da marca de uma corporação de ofício, conforme sugerido por Guénon (1983), porquanto presente na produção de uma vasta gama de artífices do mesmo período. Inclusive há várias outras marcas de livreiros e impressores, inseridas na mesma faixa cronológica, onde não figuram nem o algarismo 4 nem a cruz, o que contribui para enfraquecer a hipótese de se tratar da marca corporativa dessa categoria. 


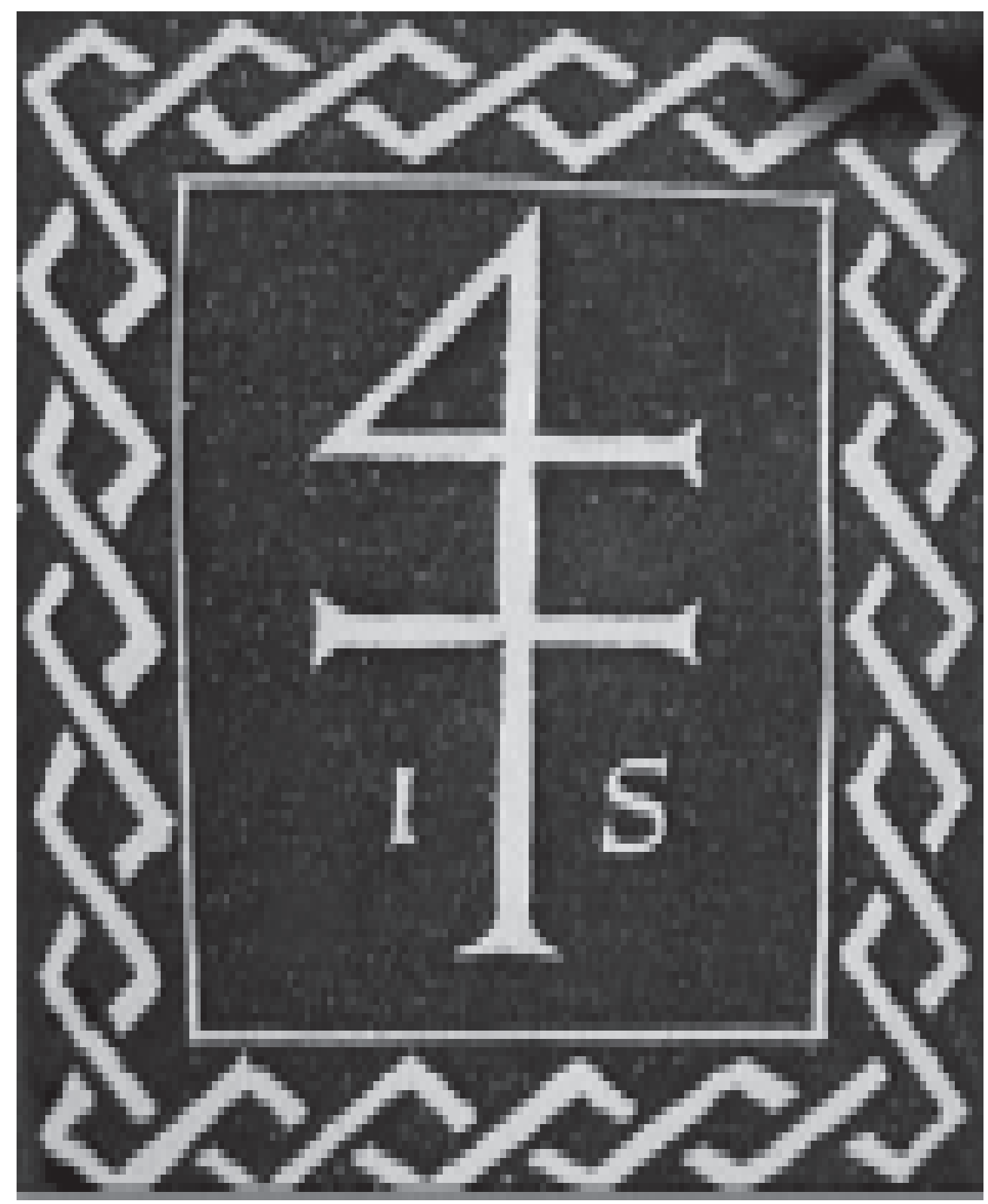

FIGURA 5 - Emblema atribuído a John Siberch, o primeiro impressor de Cambridge, aposto ao seu primeiro livro, a obra De temperamentis, de Galeno, por volta de 1521. In Douglas McMurtrie, The Book. The story of printing and bookmaking (1938, p.297-8). Acervo da Biblioteca Noronha Santos, IPHAN, Rio de Janeiro.

Por sua vez, a consulta à simbologia alquímica que figura no Medicinisch-Chymisch und Alchemistisches Oraculum, publicado em Ulm, em 1755, mostrou que efetivamente o emblema que aparece nos fundos dos cadinhos é composto por símbolos alquímicos. Seus principais elementos e operações são representados pelo número 4, em múltiplas variações, e pela cruz dupla, cardinalícia, apresentando a seguinte correspondência: 


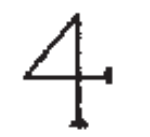

crucibulum

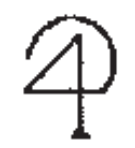

Elementa,principia

corporum

$\triangle$ Mercurius pp

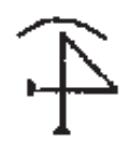

Elementa, corporum

principia

Sulphur

4

Destillare

4

Sal commune

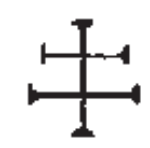

Mercurius viuus

Aurum, Sol

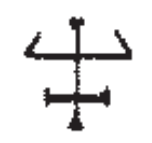

Essentia

A

FIGURA 6 - Alguns símbolos alquímicos segundo Medicinisch-Chymisch und Alchemistisches Oraculum, publicado em Ulm, em 1755. The Alchemy Web Site (www.levity.com/alchemy) home).

No caso, a intensa utilização do emblema que marca os cadinhos parece expressar uma organização mais ampla que uma corporação de ofício, abrigando diferentes categorias profissionais. As sendas trilhadas na presente investigação nos conduziram à Maçonaria, então em sua florescência máxima. Espraiando-se extraordinariamente mundo afora através de uma bem sucedida estratégia de comunicação visual, utilizou símbolos herméticos para a difusão de sua doutrina, crescentemente fortalecida pela instituição do segredo, pela aura de mistério, e também, paradoxalmente, pela implacável perseguição religiosa.

Assim, muito mais que apenas uma marca corporativa, o emblema encontrado nos fundos dos cadinhos de proveniência européia que apareceram no Brasil nos séculos XVIII e XIX, parece ser um sinal de reconhecimento maçônico, o 
sinal exterior de uma organização oculta, só partilhado por iniciados e incompreensível para os demais, difundido sub-repticiamente nos mais diversos suportes para diferentes pontos do globo.

Como ensina o Manual do Mestre (MAGISTER, 1935, p. 37), em um mesmo e único símbolo podem ser concentrados múltiplos sentidos, sejam eles de ordem moral, educativa, filosófica, iniciática ou mágica. Aparentemente estamos diante de um desses casos, de um símbolo maior que, comunicando em um nível imediato aos demais iniciados o pertencimento à Ordem, transmitia simultaneamente, em um nível mais profundo, sua filosofia, seus princípios e sua doutrina.

A Maçonaria foi fortemente impregnada pelo hermetismo e pela alquimia, o que transparece não apenas em seus ritos iniciáticos que se apóiam fortemente nos três princípios alquímicos - enxofre, sal, mercúrio, constantemente associados , bem como nos quatro elementos igualmente alquímicos, terra, fogo, água, ar, mas sobretudo na sua emblemática, fortemente calcada na simbologia dos alquimistas e hermetistas.

No caso em discussão, o elemento da cultura material que serviu como suporte para a aposição do emblema não é um objeto qualquer, mas aquele em que se opera a Grande Obra, aquele onde metais comuns são transformados, segundo os alquimistas, em ouro: o catinu, o crisol.

$\bigcirc$ vaso alquímico, hermético, segundo Chevalier e Gheerbrant ( 1996), é o local onde se operam maravilhas, é o seio materno, o útero no qual se forma um novo nascimento, daí a crença de que ele contém o segredo das metamorfoses. Ele encerra, sob diversas formas, o elixir da vida, é um reservatório de vida. O interior dos cadinhos é o lugar onde se mesclam e se fundem substâncias vitais. É o lugar onde se processam operações mágicas de transformação física e espiritual, através de rituais secretos e fortemente simbólicos. Dentro deles se opera o Grande Segredo, a arte de compreender a gênese do mundo, coroamento da sabedoria e da compreensão. Para a Maçonaria, o ouro, associado ao Sol (BIEDERMANN, 1993), representa a claridade, a iluminação finalmente alcançada, o que torna o cadinho um suporte particularmente adequado para a difusão da doutrina maçônica.

A riqueza simbólica do suporte, no entanto, não é menor que a dos símbolos que the foram apostos. Mais que do número 4, estamos diante do quaternário, que, com seu caráter axial, representa o eixo do mundo (FIGURA 7).

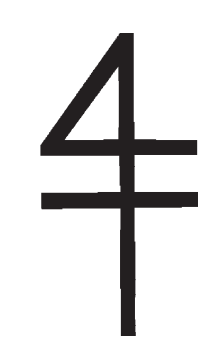

FIGURA 7 - O símbolo do quaternário

signo da cruz é uma das representações do Templo de Salomão, templo de Deus no homem (CRUZ, 1997). Mais ainda, seus quatro braços simbolizam, segundo a Filosofia Iniciática (MAGISTER, 1946), os quatro elementos alquímicos, formados pela polarização do mercúrio - a quintessência - nascida da 
união do enxofre, princípio masculino, ativo, com o sal, princípio neutro, e que correspondem respectivamente à linha vertical e horizontal da cruz (CASTRO, 1983).

A polarização do mercúrio, de acordo com a linha vertical do enxofre, produz o fogo ou princípio de expansão, como polaridade positiva que origina a força centrífuga e toda forma de irradiação. E também o ar, como polaridade negativa, que origina a força centrípeta e toda forma de movimento, rołação ou translação. A mesma polarização, segundo a linha horizontal do sal, produz a água ou princípio da umidáde, união ou solução em seu aspecto positivo; e a terra, o princípio da secura, coesão e separação em seu lado negativo. No centro da cruz a quintessência prevalece sobre o quaternário dos elementos, o cinco se impõe ao quatro. Aos quatro pontos cardeais se soma o quinto, que é o centro, ou a unidade do Grande Arquiteto. Tanto no ser humano (o microcosmo) quanto na natureza (o macrocosmo), essa "Essência Primordial" (MAGISTER, 1946) se dispõe igualmente em cruz, acompanhando os quatro elementos.

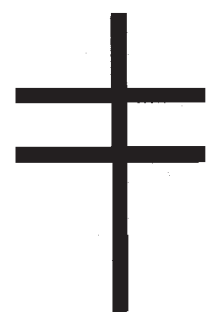

FIGURA 8 - A cruz dupla, patriarcal

A cruz dupla (FIGURA 8), patriarcal, que compõe o emblema, reúne em um mesmo signo a cruz grega, com quatro braços iguais, símbolo do macrocosmo, e a cruz latina, com um braço maior que os demais, símbolo do microcosmo, no que sugere ser uma reafirmação da teoria hermética e alquímica das correspondências. No simbolismo heráldico ela significa enigma, ponto crucial. E na ritualística maçônica ela é o símbolo dos titulares do grau 33, o mais elevado do Rito Escocês Antigo e Aceito.

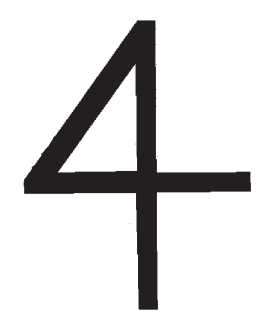

FIGURA 9 - $\bigcirc$ quatro, símbolo totalizador

Os significados simbólicos do 4 imbricam-se aos do quadrado e da cruz. $\bigcirc 4$ caracteriza o universo na sua totalidade, é símbolo de plenitude, de universalidade, símbolo totalizador, princípio organizador (FIGURA 9). O cruzamento 
de um meridiano e um paralelo geram uma cruz e dividem a Terra em quatro setores. Quatro são os pontos cardeais, as fases da lua, as estações do ano, os elementos, os humores. No plano mítico, quatro são os rios do paraíso, quatro são as letras do nome de Deus e do primeiro homem, quatro são as bestas e os cavaleiros do Apocalipse (CHEVALIER; GHEERBRANT, 1996). Quatro são as fases da transmutação, da Opus magnum, que recebem sua denominação segundo a cor que assumem os ingredientes em contato com o fogo: nigredo (mélansis, preto), albedo (leukosis, branco), citrinitas (xánthosis, amarelo) e rubedo (iôsis, vermelho) (ELIADE, 1979, p. 1 14).

A tétrade sagrada, fonte perene da Natureza, Supremo Mistério da Criação, é composta pelos signos fundamentais do ideografismo alquímico, - círculo, cruz, triângulo, quadrado. Quatro é o sinal de Hermes, do deus tetramorfo, dos quatro ventos do céu e dos quatro rostos. $\bigcirc$ quatro é o sólido (LIGOU, 1974), e mais particularmente o cubo, o cubo maçônico, ou seja, a Grande Obra realizada. Representa o Mestre, ideal de perfeição humana, a plenitude maçônica.

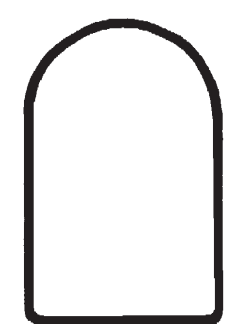

FIGURA 10 - A representação esquematizada do Templo de Salomão

signo está contido em uma forma que não é aleatória, e que sugere ser a representação esquemática do Templo de Salomão, com as duas colunas que sustentam a abóbada, tal como aparece em antigos textos maçônicos (FIGURA 10). Significativamente, não se trata mais do antigo retângulo que no século XVI envolvia o emblema de Siberch, e sim da sua transformação em um importante elemento da simbologia ritualística dos maçons. Essa forma é a mesma que abriga o painel do aprendiz, com seus símbolos (FOTOGRAFIA 9), e o painel do companheiro, com seus símbolos (FOTOGRAFIA 10). No primeiro deles ela representa ainda o portal do Templo, símbolo natural da passagem ou do ingresso nas iniciações. Repete-se na arquitetura interna, em nichos e portas do Palácio Maçônico do Lavradio (FOTOGRAFIA 1 1), o que reforça sua relação com o Templo de Sálomão. Mais ainda, aparece em nichos nas paredes da Casa da Moeda do Rio de Janeiro (FOTOGRAFIA 12), pouco funcionais por serem côncavos, o que permite supor que cumprissem uma função mais simbólica que prática. Esses nichos são posteriores à construção original da bateria de fornos e estão na mesma área em que foram recuperados os cadinhos. Não descartamos aqui a hipótese de um significado maçônico para eles, talvez associado à corporação dos moedeiros lá instalados em mais de um século de ocupação daquele espaço pela Casa da Moeda, correspondendo as estruturas em suas paredes a diferentes momentos dessa ocupação.

Interpretamos, portanto, os emblemas apostos aos cadinhos como expressões simbólicas dos mais caros e elevados ideais maçônicos, ativamente difundidos através da cultura material no século XVIII, um período de grande vitalidade na história da Ordem. O objeto escolhido para veiculá-los não foi um suporte qualquer, 


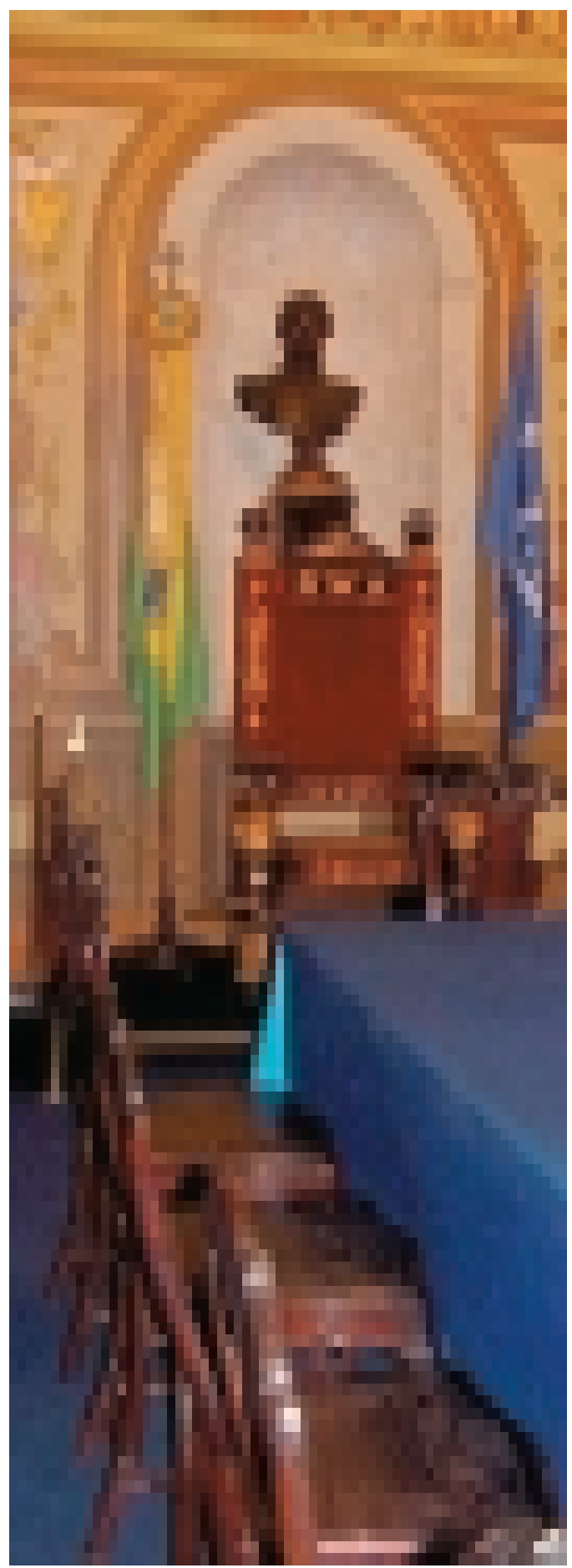

FOTOGRAFIA 1 1-Sala de reuniões do Conselho, tendo ao fundo o trono oferecido pelas lojas maçônicas ao Imperador Pedro I, Grão-Mestre do Grande Oriente do Brasil. Na parede, o nicho com a sua efígie, na forma estilizada do Templo de Salomão que se repete em outros elementos da arquitetura, como nas portas do Palácio Maçônico do Lavradio, Grande Oriente do Estado do Rio de Janeiro. Fotografia de T. Andrade Lima. 


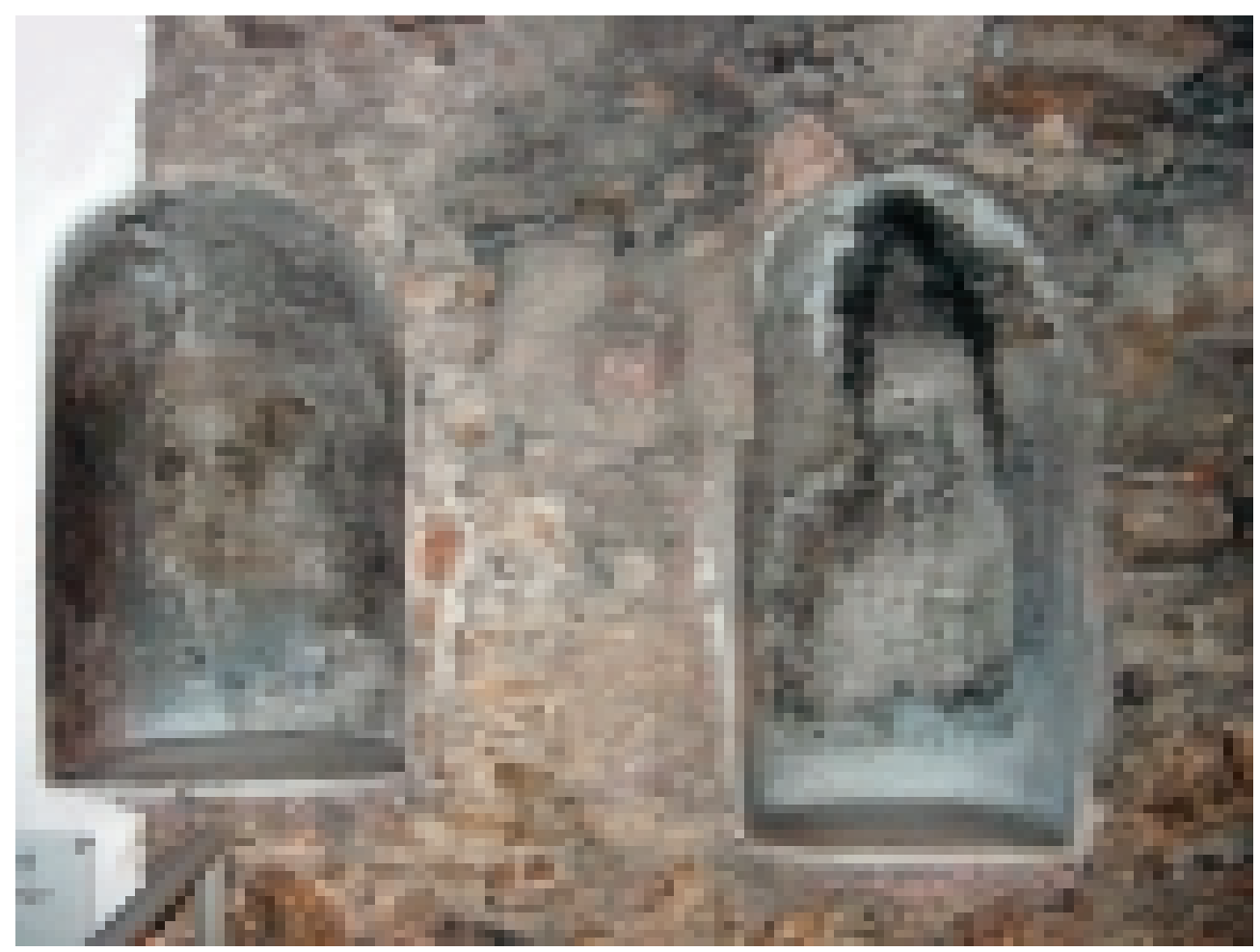

FOTOGRAFIA 12 - Nichos côncavos embutidos na parede da bateria de fornos da Casa da Moeda do Rio de Janeiro, em momento posterior à sua construção original, na forma estilizada do Templo de Salomão. Paço Imperial, Rio de Janeiro. Fotografia de T. Andrade Lima.

mas algo que, pela riqueza do seu significado simbólico, multiplicava a mensagem transmitida nos emblemas, dando-thes uma dimensão muito mais ampla.

Esses emblemas contêm saberes muito antigos, acumulados pela humanidade em sua longa trajetória, do Oriente ao Ocidente. Por diferentes meios e de múltiplas formas eles foram preservados e se mantiveram arraigados nas mentalidades até pelo menos o século XIX, muitos deles ainda vivos e presentes hoje, particularmente entre segmentos que cultivam o esoterismo, nas mais diferentes sociedades.

A Maçonaria chegou a alcançar seis milhões de adeptos em todo o mundo, segundo Dewar ( 1966). No Brasil, atualmente, há pelo menos três grandes instituições maçônicas: o Grande Oriente do Brasil, o Grande Oriente Independente e a Grande Loja. Só o Grande Oriente do Rio de Janeiro possui hoje 235 lojas, com cerca de 8.000 adeptos (GOERJ comunicação pessoal). Em plena atividade, portanto, seus símbolos permanecem vivos e continuam sendo ativamente manipulados na transmissão e difusão da doutrina mundo afora.

\section{Agradecimentos}

Ao Grande Oriente do Rio de Janeiro, GOERJ, pelas portas abertas a esta pesquisa e pelo generoso acesso à sua biblioteca, permitindo-nos a leitura de obras escritas por maçons e destinadas exclusivamente a maçons. 
A Regina Coeli Pinheiro da Silva (IPHAN), Catarina Eleonora Ferreira da Silva (IPHAN) e Carlos Alberto Etchevarne (UFBA), pelas informações prestadas sobre a escavação e recuperação de cadinhos, respectivamente no Paço Imperial do Rio de Janeiro, na Casa de Fundição de Goiás, e na Praça da Sé de Salvador. A Maria Regina Duarte, assessora da presidência da Casa da Moeda do Brasil, pelas indicações e pela disposição em colaborar com esta pesquisa. A Eugênio Ferraz, gerente regional de Administração do Ministério da Fazenda em Minas Gerais, pelas informações sobre os achados na Casa dos Contos de Ouro Preto. Ao Museu do Ouro de Sabará e à 17ª Sub-Regional do IPHAN, na cidade de Goiás, pelo atendimento atencioso que nos foi dispensado.

\section{REFERÊNCIAS}

AMADOU, Robert. L'occultisme, esquisse d'un monde vivant. Paris: Julliard, 1958.

AQUINO, São Tomaz de. A pedra filosofal e a arte da alquimia, seguido do tesouro secretíssimo de Frei Reginaldo, atribuído a São Tomaz de Aquino. [S.1.]: Editora Ciências Ocultas, [s.d.].

ARQUIVO Nacional. Diversos Códices, SDH, Cód. 807, v. 5.

ASLAN, Nicola. História da maçonaria. Rio de Janeiro: Editora Espiritualista, 1959.

BERTHELOT, M. Les origines de l'alchimie. Paris: George Steinheil, 1885.

CAMINO, Rizzardo da; CAMINI, Odéci Schilling. Vade-mecum do simbolismo maçônico. $2^{\text {a }}$ ed. Rio de Janeiro:Aurora, [s.d.].

BIEDERMANN, Hans. Dicionário ilustrado de símbolos. São Paulo: Melhoramentos, 1993.

BOSCHI, Caio César. Os leigos e o poder. Irmandades leigas e política colonizadora em Minas Gerais. São Paulo: Ática, 1986.

BOXER, Charles R. Catálogo das cartas dirigidas a Manuel de Souza, Oficial das Casas de Moeda do Brasil. Revista do IHGB, v. 266, p. 3-40, jan./mar. 1965.

CARVALHO,Assis. Símbolos maçônicos e suas origens. Londrina: Editora e Gráfica Cotação, 1997.

CASTELLANI, José. Liturgia e ritualística do grau de aprendiz maçon em todos os ritos. $2^{\mathrm{a}}$ ed. São Paulo:A Gazeta Maçônica, 1987a.

Liturgia e ritualística do grau de companbeiro maçon nos ritos Escocês Antigo e Aceito, Moderno, Adoniramita, Brasileiro, York, Schroeder. São Paulo:A Gazeta Maçônica, 1987b. 
CASTRO, Boanerges B. O simbolismo dos números na Maçonaria. $2^{\text {a }}$ ed. Rio de Janeiro: Grafica Editora Aurora, 1983.

CATÁLOGO das cartas régias, provisões, alvarás, avisos, portarias, etc., de 1662 a 1821, existentes no Arquivo Nacional. Publicações Históricas, Rio de Janeiro, v. 1.

CHEVALIER,Jean; GHEERBRANT,Alain.Dicionário de símbolos. $10^{\mathrm{a}}$ ed. Rio de Janeiro:José Olympio, [s.d.].

CRUZ,Almir Sant'Anna.Simbologia maçônica dos painéis. Londrina:Editora Maçônica “ATrolha”, 1997.

DAVIS, Hugh William. Devices of the early printers, 1457-1560. Their history and development. London: [s.n.], 1935.

DEWAR, James. The unlocked secret. Freemasonry reexamined. London:William Kimber, 1966.

DREYFUS, Jenny. João Manso Pereira e sua suposta fábrica de louças. Anais do Museu Histórico Nacional, v. XIV, p. 5-28, 1953.

DUBREIL,J.P.Histoire des francs-maçons. Tome $1^{\mathrm{er}}$. Bruxelles:H.- I.- G. François, Librairie-éditeur, 1838.

ELIADE, Mircea. Ferreiros e alquimistas. Rio de Janeiro: Zahar, 1979.

ESCHEWEGE,W. L. von. Pluto brasiliensis. São Paulo: Companhia Editora Nacional, 1949.

FEBVRE, Lucien; MARTIN, Henri-Jean. O aparecimento do livro. São Paulo: Hucitec, 1992.

FERRAZ, Eugenio. A casa dos contos de Ouro Preto. Ensaio histórico e memória da restauração no ano do seu bicentenário. Belo Horizonte: Multicor Artes Gráficas, 1985.

FERREIRA DA SILVA, Catarina Eleonora; PARDI, Maria Lucia Franco.A pesquisa arqueológica na Casa da Fundição do Ouro de Goiás, GO. Dédalo. São Paulo: MAE/USP, 1989. (Publicações avulsas, n. 1).

FILGUEIRAS, Carlos A. L.João Manso Pereira, químico empírico do Brasil Colonial. Quimica Nova, v. 16, n. 2 , p. $155-160,1990$.

FINDEL, J. G. Histoire de lafFranc-maçonnerie. Tome II. Paris: Librairie Internationale, 1866.

FOURNIER, P. S. Manuel typographique 1764-1766. Paris: [s.n.], [s.d.].

FRUTIGER,Adrian.Sinais e símbolos. Desenho, projeto e significado. São Paulo: Martins Fontes, 1999.

GOLDFARB, Ana Maria Alfonso. Da alquimia à química. Um estudo sobre a passagem do pensamento mágico-vitalista ao mecanismo. São Paulo: Nova Stella; Edusp, 1987.

GONÇALVES, Cleber Baptista. Casa da moeda do Brasil. $2^{\text {a }}$ ed. Rio de Janeiro: Casa da Moeda do Brasil, 1989. 
GUÉNON, René. Os símbolos da ciência sagrada. 9a ed. São Paulo: Pensamento, 1993.

HARTT, Carlos Frederico. Contribuições para a etnologia do Vale doAmazonas. Arquivos do Museu Nacional, v. VI, 1881.

JACOB, Margareth C. The radical enlightnment: pantheists, freemasons and republicans. London: George Allen \& Unwin, 1981.

LABOULAYE, Charles Pierre Lefebvre du.Dictionnaire des arts et manufactures et de l'agriculture formant un traité complet de technologie. 7ème. ed. Paris: Libr. du Dictionnaire des Arts et Manufactures, 1891.

LÉVI-STRAUSS, Claude. A oleira ciumenta. São Paulo: Brasiliense, 1996.

LEXIKON, Herder. Dicionário de simbolos. São Paulo: Cultrix, 1990.

LIGOU, Daniel.Dictionnaire universel de la franc-maçonnerie. [S.1.]:Éditions de Naverre,Éditions du Prisme, 1974

LIMA,Adelino de Figueiredo. Nos bastidores do Mistério. 3a. ed. Rio de Janeiro: Spiker, 1958.

LUCAS, Fábio. Luzes e trevas: Minas Gerais no século XVIII. Belo Horizonte: Ed. UFMG, 1998.

McMURTRIE, Douglas. The Book. The story of printing and bookmaking. $2^{\text {nd }}$ ed. New York: CoviciFriede, 1938.

MAGISTER. Manual del aprendiz. Estudo interpretativo sobre el valor iniciático de los símbolos y alegorías del primer grado masónico y la mística doctrina que en ellos se encierra. Barcelona: Editorial Maynadé, 1934. Biblioteca Filosófica Masónica.

Manual del compañero. Estudo interpretativo de los simbolos y alegorias del segundo grado masonico. La Masoneria Revelada. Buenos Aires: Editorial Kier, 1946.

.Manual del maestro. Barcelona: Editorial Maynadé, 1935. Biblioteca Filosófica Masónica.

MARTINS, Wilson. A palavra escrita. História do livro, da imprensa e da biblioteca. $2^{\text {a }}$. ed. São Paulo: Ática, 1996.

MELLOR,Alec. Dictionnaire de la franc-maçonnerie et des francs-maçons. Paris: Belfond, 1983.

NAUDON, Paul.Les origines religieuses et corporatives de la Franc-Maçonnerie. 3ème. ed. Dervy, Paris: [s.n.], 1972.

PINHEIRO DA SILVA, Regina Coeli; MORLEY, Edna; FERREIRA DA SILVA, Catarina Eleonora. A pesquisa arqueológica: primeiras notas. Revista do Patrimônio Histórico e Artístico Nacional, n. 20, p. 158-165, 1984.

PINTO, Américo Cortez. Da famosa arte da imprimissão: da imprensa em Portugal às cruzadas d'além mar. Lisboa: Editora Ulisseia, 1948. 
PIRENNE, Henri. História econômica e social da Idade Média. 4ª ed. São Paulo: Mestre Jou, 1968.

READ, John. Alchemy and alchemists. Nature, v. 168, p. 759-762, 1951.

RIS-PAQUOT. Dictionnaire encyclopédique des marques et monogrammes. Paris: Librairie Renouard, [s.d.].

SCHURÉ,Edouard.Hermes. Os grandes iniciados: esboço da história secreta das religiões. São Paulo: Martin Claret, 1986.

VARGAS, Milton. A origem da alquimia: uma conjetura. Prefácio à Da alquimia à química. Um estudo sobre a passagem do pensamento mágico-vitalista ao mecanismo. São Paulo: Nova Stella; Edusp, 1987. p. 11-31.

VIEIRA, David Gueiros. O protestantismo, a maçonaria e a questão religiosa no Brasil. $2^{\mathrm{a}}$ ed. Brasilia: Editora UnB, 1980.

Artigo apresentado em 10/2003. Aprovado em 1 1/2003. 


\section{RESUMOS/ABSTRACTS}

Alquimia, Ocultismo, Maçonaria: o ouro e o simbolismo hermético dos cadinhos (Séculos XVIII e XIX)

Tania Andrade Lima, Marilia Nogueira da Silva

Este artigo apresenta a arqueologia das enigmáticas marcas impressas na base de cadinhos dos séculos XVIII e XIX recuperados nas escavações da Casa da Moeda do Rio de Janeiro, na década de 1980, e a explanação do seu significado simbólico à luz da alquimia, do ocultismo e da Maçonaria. Espraiando-se extraordinariamente mundo afora através de uma bem-sucedida estratégia de comunicação visual, a Maçonaria utilizou símbolos herméticos para a difusão de seus princípios nos mais diferentes suportes. Aparentemente estamos diante de um sinal de reconhecimento maçônico, o sinal exterior de uma organização oculta, só partilhado por iniciados e incompreensível para os demais, que contribuiu para difundir veladamente a doutrina maçônica por diferentes pontos do globo.

PALAVRAS-CHAVE: Cadinhos.Alquimia. Maçonaria.

Anais do Museu Paulista. São Paulo. N. Sér. v. 8/9. p.9-54 (2000-2001). Editado em 2003.

Alchemy, Occultism, Freemasonry: the gold and the hermetic symbolism of the crucibles $118^{\text {th }}$ and $19^{\text {th }}$ centuries

Tania Andrade Lima, Marília Nogueira da Silva

This paper presents the archaeology of enigmatic signs printed on the bases of 18th and 19th century crucibles recovered from excavations at the Brazilian Mint in Rio de Janeiro during the 1980s; as well as the explanation of their symbolic meaning in the light of alchemy, occultism and Freemasonry. Spreading extraordinarily around the world through a well succeeded strategy of visual communication, the Freemasonry made use of hermetic symbols printed and/or attached to different supports with the purpose of diffusing its principles. We are, apparently, before a sign of Masonic recognition, the external sign of an occult organization, exclusively shared by the initiated and in turn incomprehensible for the rest. This contributed to the diffusion of the Freemasonry doctrine to different points of the world, always in a cloaked manner.

KEYWORDS: Crucible.Alchemy. Freemasonry.

Anais do Museu Paulista. São Paulo. N. Sér. v. 8/9. p.9-54 (2000-2001). Editado em 2003

Em casas térreas com alcovas. Formas de morar dos setores médios em São Paulo entre 1875 e 1900

Maria Luiza Ferreira de Oliveira

Nosso objetivo é compreender quais eram as formas de morar das famílias de médias posses em São Paulo. Esse caminho será percorrido, sobretudo, procurando observar continuidades e transformações na moradia das camadas médias urbanas nas últimas décadas do século XIX, a partir do novo vocabulário formal que estava surgindo.

PALAVRAS-CHAVE: Setores Médios. Domesticidade. Urbanização. Moradia. Mobiliário.

Anais do Museu Paulista. São Paulo. N. Sér. v. 8/9. p.55-76 (2000-2001). Editado em 2003.

In one-story houses with alcoves. Ways of living of the middle class sectors

of society of São Paulo between 1875 and 1900

Maria Luiza Ferreira de Oliveira

Our aim is to understand which were the ways the middle class sectors of the society of São Paulo lived. This track will be covered, above all, with a search for the continuities and transformations in the housing of the urban middle classes in the last decade of the $19^{\text {th }}$ century, starting from the new formal vocabulary that was coming out.

KEYWORDS: Middle-class sectors. Domesticity. Urbanization. Housing. Furniture 